https://doi.org/10.11646/phytotaxa.427.2.1

\title{
A taxonomic revision of Geschollia (Asparagaceae, Urgineeae)—from a monotypic genus towards its diversification, including the description of five new species
}

\author{
MARIO MARTÍNEZ-AZORÍN ${ }^{1 *}$, ANTHONY P. DOLD², MANUEL B. CRESPO ${ }^{1}$, MICHAEL PINTER ${ }^{3}$, MARÍA \\ ÁNGELES ALONSO-VARGAS ${ }^{1} \&$ WOLFGANG WETSCHNIG ${ }^{3}$ \\ ${ }^{1}$ Depto. Ciencias Ambientales y Recursos Naturales (dCARN), Universidad de Alicante, P. O. Box 99, E-03080 Alicante, Spain; \\ e-mail:mmartinez@ua.es \\ ${ }^{2}$ Selmar Schonland Herbarium, Department of Botany, Rhodes University, Grahamstown 6140, South Africa. \\ ${ }^{3}$ Institute of Biology, Division of Plant Sciences, NAWI Graz, Karl-Franzens University Graz, Holteigasse 6, A-8010 Graz, Austria. \\ "author for correspondence
}

\begin{abstract}
In the frame of a taxonomic revision of Hyacinthaceae subfamily Urgineoideae (Asparagaceae tribe Urgineeae) combining morphological and genetic data from numerous samples across its whole range of distribution, we here present a taxonomic revision of Geschollia, a genus originally accepted as monotypic to include $G$. anomala. This genus was characterized by the single, synanthous, terete leaf; long racemose inflorescence; tepals connate for ca. $1 \mathrm{~mm}$ and reflexed at anthesis; spreading to patent stamens; and small polygonal seeds. Our morphological studies in combination with phylogenetic analyses evidence that Geschollia is indeed a strongly supported monophyletic group, which includes eight species matching most of the features cited above. In this context, we here describe five new species in this genus and accordingly expand the original characterization of Geschollia to accommodate these new taxa. Furthermore, two new combinations are presented for previously described species. An identification key is provided for all accepted species in the genus.
\end{abstract}

Keywords: distribution, ecology, Hyacinthaceae, nomenclature, taxonomy, Urgineoideae

\section{Introduction}

Hyacinthaceae includes ca. 1000 species of bulbous plants distributed in Africa, Europe and Asia, with a single genus, Oziroë Rafinesque (1837: 53), in South America (Speta 1998a, 1998b, APG 2003). Four monophyletic subfamilies are accepted in Hyacinthaceae: Hyacinthoideae, Ornithogaloideae, Oziroëoideae and Urgineoideae (Speta 1998b, Pfosser \& Speta 1999, Manning et al. 2004, Martínez-Azorín et al. 2011a). Alternatively, Hyacinthaceae are treated as Asparagaceae subfamily Scilloideae, and consequently the former subfamilies are reduced to the tribes Hyacintheae, Ornithogaleae, Oziroëeae and Urgineeae respectively (APG 2009, 2016, Chase et al. 2009).

Urgineoideae commonly show short flowering periods, commonly proteranthous leaves, and small size in several species, which have greatly hindered a satisfactory taxonomic circumscription, which is still uncertain in many instances. Although some studies accept only ca. 100 species in Urgineoideae (Manning et al. 2004), we consider it to include at least 200 species given our current knowledge of this subfamily across their wide distribution range, and the lack of comprehensive taxonomic revisions (Martínez-Azorín et al. 2019b).

In recent decades subfamily Urgineoideae has been especially controversial regarding the generic circumscription (Speta 1998a, 2001, Pfosser \& Speta 2001, 2004, Manning et al. 2004, Pfosser et al. 2012, Martínez-Azorín et al. 2013a, 2013b, 2016, 2017, 2018a, 2018b, 2019a, 2019b, Pinter et al. 2013, Crouch \& Martínez-Azorín 2015, Crouch et al. 2018, Manning \& Goldblatt 2018). Indeed, on the one hand, Manning et al. (2004) presented a synthetic approach, accommodating the enormous variation in floral, fruit, seed and vegetative morphologies, and synonymizing several traditionally accepted genera with distinct morphological syndromes. An example of this broad generic circumscription approach was applied by Manning \& Goldblatt (2018) to Drimia Jacq. ex Willdenow (1799: 165), which in this sense, however, contains multiple morphological exceptions or opposites in vegetative and most notably reproductive organs 
(Martínez-Azorín et al. 2019b). On the other hand, Speta (1998a, 1998b, 2001) and Pfosser \& Speta (2001) favoured a more analytic approach, in which about 20 different genera were accepted. However, some of these genera have either proved to be, or been interpreted as, para- or polyphyletic (Pfosser \& Speta 2001, 2004, Manning et al. 2004, Pfosser et al. 2012).

Interestingly, molecular studies on Urgineoideae (Pfosser \& Speta 2001, 2004) showed that Drimia anomala (Baker 1870: t. 178) Baker (1897: 442) from South Africa form an independent well supported clade, leading Speta (2001) to describe the monotypic genus Geschollia Speta (2001: 169) to include this species, which was originally described as Ornithogalum anomalum Baker (1870: t. 178). In these phylogenetic analyses (Pfosser \& Speta 2001, 2004) Geschollia formed a sister clade to Boosia Speta (2001: 168) and Urgineopsis Compton (1930: 107) although relationships among the latter genera were weakly supported. However, some years later, Pfosser et al. (2012) found Geschollia plus Urgineopsis to form a monophyletic clade with moderate support, where both latter genera appeared as supported sister clades.

Our phylogenetic analyses included more than 250 samples of all genera in Urgineoideae from its global distribution, using $t r n L-F$, matK, and $y c f$ cpDNA sequences, as well as a nuclear region (Agt1). Among these samples, 21 belonged to Geschollia, covering some populations of G. anomala (Baker 1870: t. 178) Speta (2001: 169) and other species in the genus. Our phylogenetic trees recovered Geschollia, including some undescribed species, as monophyletic with a strong bootstrap support (see fig. 3 in Martínez-Azorín et al. 2018).

Baker (1870) described and illustrated Ornithogalum anomalum from a plant native to the Cape of Good Hope (South Africa) sent by Thomas Cooper. This plant was cultivated in England by W.W. Saunders and was illustrated in the Refugium Botanicum (Baker 1870) (Fig. 1). In the protologue, both the diagnosis and illustration show a plant having a semi-epigeal green bulb with a single, terete and fleshy leaf (ca. 6-7 mm wide at the base), and a long raceme with 30-40 flowers. Although Baker (1870) placed the new species in Ornithogalum, he clearly stated that it differed from all the other species of this genus in many features. Therefore, he described the subgenus Ledebouriopsis to accommodate this new species. Later, Baker (1873) cited specimens collected by P. MacOwan near Somerset East, in the Eastern Cape Province of South Africa, as further material doubtfully belonging to Ornithogalum.

Bentham \& Hooker (1883) were the first to relate $O$. anomalum to the subfamily Urgineoideae, and commented that this species may be included in Drimia. However, it was Baker (1897) who doubtfully placed this species in Drimia (subfamily Urgineoideae), providing a new combination and highlighting the spurred character of the bracts. Moreover, he included Urginea eriospermoides Baker (1887: 126) among synonyms and added further collections made by $\mathrm{H}$. Bolus and W. Tyson.

Dyer (1951) first commented and illustrated (Fig. 2) on the peculiar habit of the leaf in D. anomala, i.e. its cylindric and solid aspect, its length and diameter, and its peculiar withering process that occurs before maturity, starting from the tip and being arrested at different stages, according to moisture conditions. Dyer also noticed that the cultivated specimen with a complete leaf figured in Baker (1870) differed markedly from the plant he was studying, because in the latter the leaf had withered extensively. He also suggested that Cooper obtained bulbs in the Eastern Cape Province, so that the figured plant was collected there.

Jessop (1977) studied a selection of herbarium specimens covering a large distribution area in the southern part of central South Africa, which he attributed to Drimia anomala and that presented a considerable variation in morphology, especially regarding flower colour, being white, pale pink, beige, yellow or greenish.

Recently, Manning \& Goldblatt (2018) included Drimia anomala in Drimia sect. Ledebouriopsis (Baker 1873: 284) Manning \& Goldblatt (2018: 24), which covered 11 species with variable morphology and being polyphyletic based on the phylogenetic studies by Pfosser \& Speta $(2001,2004)$ and our unpublished results (Martínez-Azorín et al. in prep.).

Our field work in South Africa during the last decade has shown that some undescribed species share the main diagnostic characters of Geschollia, such as the single (rarely two), terete leaf, the long racemose inflorescence, and the angulose or polygonal small seeds, but differ in distinct characters. We here present a taxonomic revision of Geschollia in which five new species are described and the genus circumscription is expanded to accommodate these taxa. Furthermore, Ornithogalum calcaratum Baker (1874: 723) and Drimia occultans Williamson (2012: 287), which also share the main diagnostic characters of Geschollia, are transferred to the latter genus, a solution also supported by our unpublished phylogenetic studies. A complete morphological description is presented for all accepted taxa, as well as information on ecology and distribution. An identification key is presented to facilitate identification and further research in the genus. 


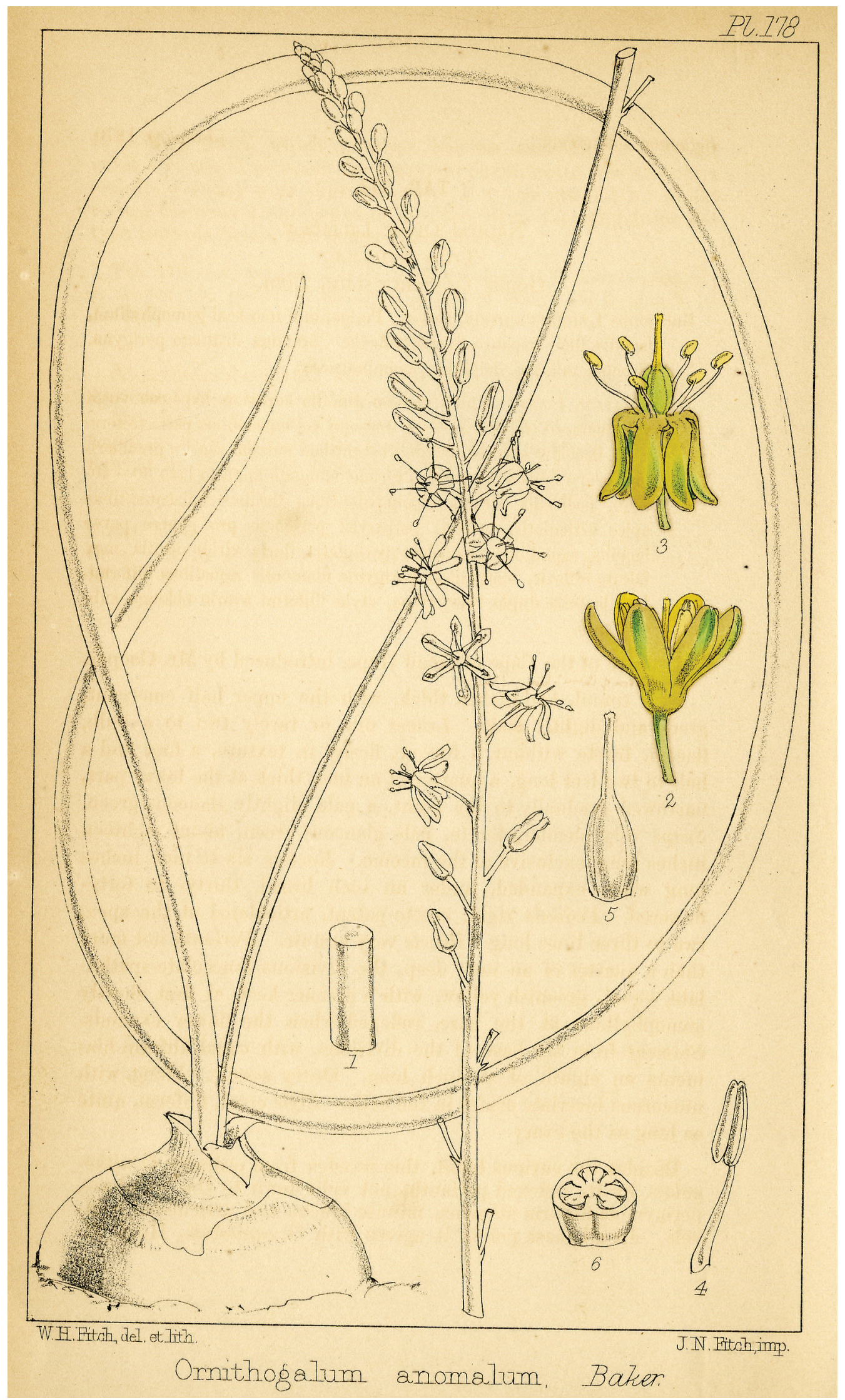

FIGURE 1. Lectotype (or perhaps holotype) of Ornithogalum anomalum Baker. 


\section{Materials and methods}

Detailed morphological studies were undertaken on cultivated specimens following the terminology used for species of Hyacinthaceae in Martínez-Azorín et al. (2007, 2009). Herbarium specimens from the herbaria ABH, B, BLFU, BM, BOL, E, G, GZU, GRA, HAL, K, L, LINN, M, MO, NBG, NU, NY, P, PRE, S, TCD, UPS, WU, Z, ZSS and ZT (acronyms according to Thiers 2019) were studied. Authors of the cited taxa follow IPNI (2019). Orthography of geographical names and grid-number system follows Leistner \& Morris (1976). Measurements of leaf width and tepals, stamen and ovary size presented in the morphological descriptions and the identification key were taken on fresh material. Measurements on dry specimens can show considerably lower values.

\section{Results and discussion}

Our field work in South Africa and Namibia revealed the existence of a large morphological variability of plants attributed to G. anomala and other related species that were widely distributed in this country, with the highest diversity and abundance in southern central South Africa. Our unpublished phylogenetic results showed a genetic variability that together with a distinct morphological differentiation support the recognition of eight species within this genus, five of them being new and two new combinations, requiring an expansion of the genus morphological characterization.

Manning \& Goldblatt (2018) commented that capsules of D. anomala are remarkably small (4-6 mm long) considering the inflorescence size, and contain small, strongly angled seeds $1.5-2.0 \mathrm{~mm}$ long. This is one of the best diagnostic characters of Geschollia, together with the single, terete leaf that commonly withers from the tip (showing abscissing plates), and the long-racemose inflorescence. Manning \& Goldblatt (2018) accepted two further species here included in Geschollia: Drimia occultans, a species that shares the diagnostic characters of the genus, including the small capsules with small, angled, narrowly pyramidal seeds, and Drimia calcarata (Baker 1874: 723) Stedje (1987: 663). However, for this latter species we restrict its range to the Eastern Cape Province, with occasional disjunct populations occurring in the western and eastern regions of this country.

\section{Taxonomic treatment}

Geschollia Speta (2001: 169)

$\equiv$ Ornithogalum subgen. Ledebouriopsis Baker (1870: 178) $\equiv$ Drimia subgen. Ledebouriopsis (Baker) Baker (1897: 437) $\equiv$ Drimia sect. Ledebouriopsis (Baker) J.C.Manning \& Goldblatt (2018: 24) pro parte (only Drimia anomala, D. occultans and D. calcarata s.str.).

Typus generis:-Geschollia anomala (Baker) Speta

Deciduous bulbous plant. Bulb hypogeal or rarely semi-epigeal, mostly solitary but rarely proliferous, usually with compact scales but rarely loose, outer scales brownish and membranous. Roots thickened and branched. Leaf solitary (rarely 2), terete, green, commonly leathery, synanthous or proteranthous, deciduous to evergreen, $0.5-7 \mathrm{~mm}$ in diameter, smooth, glabrous, usually withering from the tip showing transverse abscission plates. Inflorescence 1 or rarely 2 per bulb, long racemose, erect or slightly bent; peduncle elongated, erect, smooth or sometimes distinctly papillose at base; flower pedicels 2-30 mm long, subpatent. Bracts lanceolate, acute, the lowermost with a broad spur usually longer than the blade; bracteoles absent. Flowers pentacyclic, trimerous, stellate, erect-patent, diurnal, usually opening in the afternoon and withering in the evening. Flower yellowish, orange, greenish or white, with a discrete brownish, green or purple stripe along the middle of the perigone segments, more evident on the abaxial side. Tepals 6 , biseriate, spreading to reflexed at full anthesis, with the base usually shortly connate for ca. $1 \mathrm{~mm}$ but almost free in general appearance. Stamens 6; filaments filiform, slightly fusiform, erect to spreading, adnate to the base of tepals, commonly glabrous and smooth, sometimes distinctly papillate; anthers yellow, oblong, dehiscing along their whole length. Ovary ovate to oblong, attenuate to truncate at top, green, sometimes with white maculae; style white, narrowly filiform to obtriangular, distinctly trigonous in section, as long as or longer than the ovary; stigma slightly three-lobed and papillose. Capsule ovate-globose, small, 3-6 mm long, trigonous, loculicidal, the 3 valves splitting to the base, with the withered perigone segments circumscissile below and forming an apical cap. Seeds polygonal or irregularly compressed, commonly narrowly pyramidal, small, 1-2(-2.8) mm long, light brown to black, with wrinkled-rugose testa. 
Eponymy:- Named after Georg Scholl (1751-1831), a gardener at Schönbrunn botanic garden, Vienna, who together with Franz Boos, travelled to South Africa between 1786 and 1799 collecting plants and animals for Emperor Joseph II of Austria. Their efforts greatly enriched the Schönbrunn gardens and provided much of the material for the beautiful illustrated works of N.J. Jacquin (Gunn \& Codd 1981: 317; Glen \& Germishuizen 2010: 386).

Main diagnostic characters and taxonomic relationships:- Species of Geschollia share a syndrome of morphological characters that allow clear recognition, such as the single terete leaf (rarely 2), the long racemose inflorescence (rarely short and few flowered); flowers with shortly connate tepals at base, with spreading to reflexed free portion at anthesis; suberect to spreading filaments; and comparatively small capsules with small polygonal or irregularly compressed angled seeds.

As noted by Martínez-Azorín et al. (2019b), the basic trimerous flower pattern in Hyacinthaceae is constant, as in most of petaloid monocot families, and variation mainly regards the degree of connation of tepals, adnation and/ or connation of stamens and morphology of the gynoecium, which are the main basis for generic circumscriptions. However, based on previous phylogenetic studies, it is evident that these latter flower characters evolved several times as convergent events in relation to independent and usually distant clades or genera (Martínez-Azorín et al. 2011a). Therefore, quantitative and qualitative characters of flower morphology must be combined with vegetative, fruit and seed characters, together with biogeographic patterns, in order to recognize supported genera, as evidenced by Martínez-Azorín et al. (2011a).

Flower morphology in Geschollia seems to be unspecialized, as tepals are nearly free to shortly connate for about $1 \mathrm{~mm}$ at the base, hence not providing a constant morphological feature. Accordingly, this character alone should not be used for generic circumscription. Qualitative characters of flower and inflorescence, together with fruit and seed morphology and vegetative characters, allow a confident identification of Geschollia species, and provide also a good basis for a multigeneric treatment in Urgineoideae (Martínez-Azorín et al. in prep.). In this treatment, the number of accepted genera is more or less the same than that widely accepted in Hyacinthoideae, where Manning et al. (2004) included 11 genera for southern Africa, to which ca. 20 further genera occurring in the northern hemisphere (cf. Speta 1998) have to be added.

Ecology:- Species of Geschollia are usually found on patches of open vegetation, in sandy or loamy soil, on flats or rocky ground on mountain slopes.

Distribution:- The center of diversity of Geschollia occurs in south-central South Africa from the Little Karoo in the west to the Eastern Cape, with one species extending to southern Namibia and northwestern Northern Cape Province, and some disjunct populations occurring in southwestern and eastern South Africa.

Karyology:-Unknown (cf. Goldblatt et al. 2012).

Number of species:- In the present revision, 8 species are included in Geschollia.

1. Geschollia anomala (Baker 1870: t. 178) Speta (2001: 169) $\equiv$ Ornithogalum anomalum Baker (1870: t. 178), basion. $\equiv$ Drimia anomala (Baker 1870: t. 178) Baker (1897: 442)

Type:- SOUTH AFRICA. Cape of Good Hope, "sent from South Africa by Mr Thos. [Thomas] Cooper". (Holotype: icon in Baker (1870:

Plate 178) (Fig. 1); epitype (designated here): Fort Beaufort (3226): 22 km south of Bedford on R350, Normandale Farm, ca. 160

$\mathrm{m}$ SE from farmhouse (-CC), elevation $649 \mathrm{~m}, 8$ December 2018 (in flower and fruit), A.P.Dold 16047 GRA!).

= Urginea eriospermoides Baker (1887: 126). Type: SOUTH AFRICA, MacOwan 292-72 (holotype: K000257355!).

Bulb hypogeal or semiepigeal and photosynthetic, ovoid to subglobose, sometimes depressed in old plants, $2-7 \times$ 2-8 cm, with compact scales, outer scales brownish to greyish and membranous, sometimes with a hypogeal bulb neck covered with papery brown cataphylls, sometimes transversally banded. Roots thickened and branched. Leaf solitary (rarely 2 in cultivation), terete, $10-35 \times 0.3-0.7 \mathrm{~cm}$, suberect, curved, leathery, smooth, glabrous, uniformly shiny green or sometimes striated, presenting longitudinal green nerves alternating with regions of shining, refractive cells under the microscope, synanthous or proteranthous, deciduous or evergreen, usually withering from the tip, with transverse abscission plates. Inflorescence 1 or rarely 2 per bulb; raceme elongated, 7-30 cm long, with 20-80 flowers, erect or slightly curved; peduncle elongated, erect, smooth or rarely minutely papillate at the base; flower pedicels 4-10 mm long, subpatent. Bracts lanceolate, acute, 1-2 mm long, the lowermost with a broad spur 2-5 mm long; bracteoles absent. Flowers pentacyclic, trimerous, stellate, erect-patent, diurnal. Flowers yellow, green, white or pink, with a discrete green, brown or purple stripe along the middle of the perigone segments, more evident on the abaxial side. Tepals 6 , biseriate, strongly reflexed at full anthesis, shortly connate at the base for $0.5-1 \mathrm{~mm}$, lanceolate-oblong, 4-6 mm long. Stamens 6; filaments filiform to narrowly fusiform, $2-4 \mathrm{~mm}$ long, attenuate to the apex, spreading, never approaching the style, adnate to the base of the tepals for less than $1 \mathrm{~mm}$, smooth; anthers yellow, oblong, medifixed, 


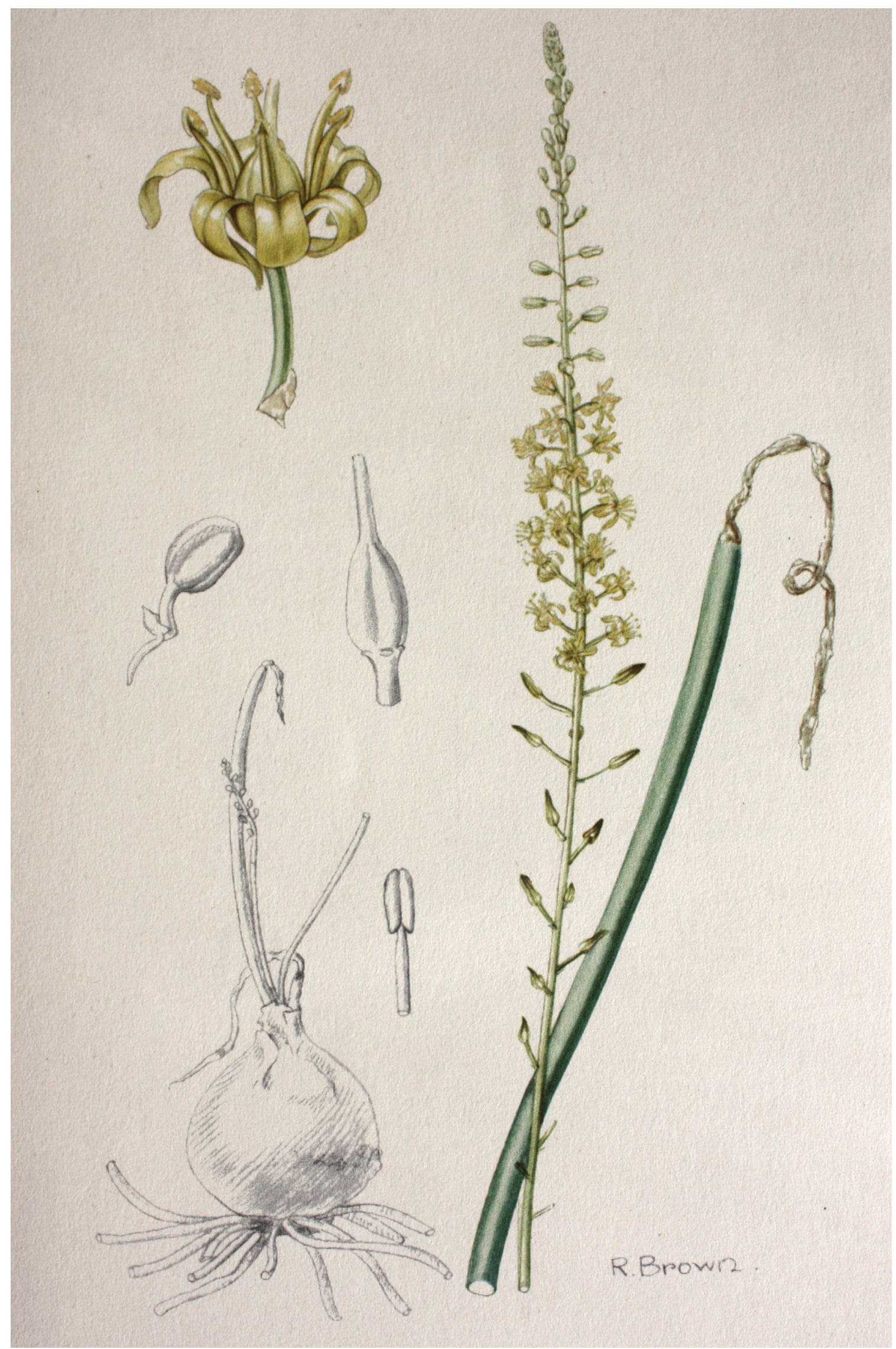

FIGURE 2. Illustration of Geschollia anomala (Baker) Speta (under Drimia anomala) published by Dyer in Flowering Plants of Africa. 
1-2 mm long, dehiscing along their whole length; pollen yellow. Ovary ovate to oblong, attenuate to truncate at the top, $1.5-2.5 \times 1-1.5 \mathrm{~mm}$, green, sometimes with white maculae; style white, narrowly columnar, 2-3.2 $\mathrm{mm}$ long, trigonous in section, about as long as ovary or slightly longer; stigma slightly three-lobed and papillose. Capsule ovate, trigonous, $4-5.8 \times 2.5-4.1 \mathrm{~mm}$, loculicidal, the 3 valves splitting to the base, with the withered perigone segments circumscissile below and forming an apical cap. Seeds polygonal or irregularly compressed, commonly narrowly pyramidal, 1.1-2 $\times$ $0.6-1 \mathrm{~mm}$, light brown to black, with wrinkled-rugose testa.

Etymology:-Named after the deviant characters of this species with regards to Ornithogalum, especially when considered in a narrow sense (see Martínez-Azorín et al. 2011a).

Phenology:-Geschollia anomala flowers after rain almost any time of the year with a peak in summer, between October and January.

Habitat:- G. anomala is found in the Albany Thicket, Fynbos, Grassland, Nama-Karoo, Savanna and Succulent Karoo biomes, as well as the Indian Ocean Coastal Belt and various azonal vegetation types (Mucina \& Rutherford 2006). It grows in a wide range of soils from sandy to rocky and usually occurs in open vegetation and sunny position.

Distribution:- G. anomala is mostly distributed in the Eastern Cape Province of South Africa (Fig. 3).

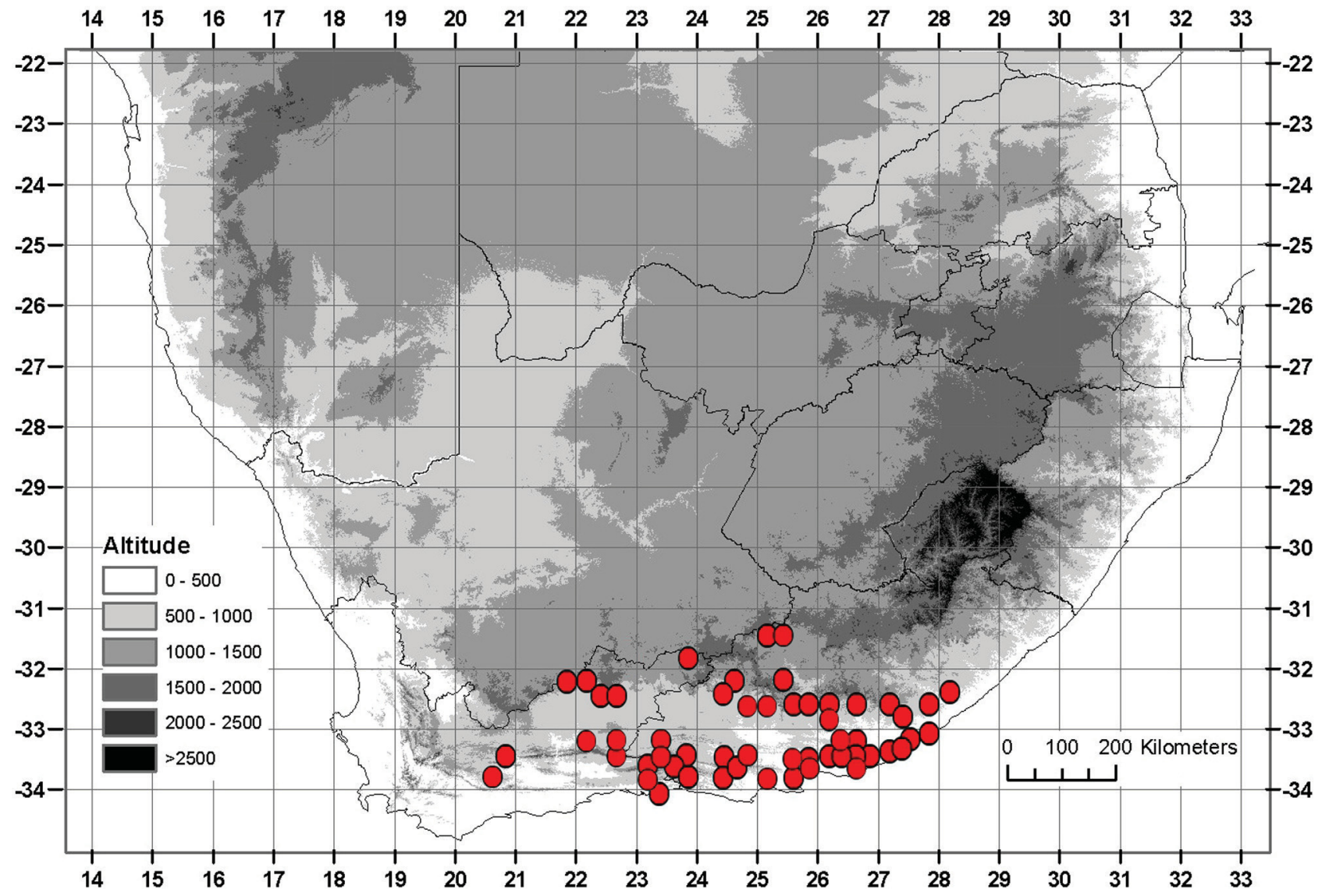

FIGURE 3. Distribution of studied materials of Geschollia anomala in South Africa.

Diagnostic characters and morphological variability:-Geschollia anomala, as circumscribed here, shows a considerable variability in morphology, but it can be recognized by the relatively thick leaf 3-7 $\mathrm{mm}$ wide; the long, multiflowered, racemose inflorescence with pedicels up to $10 \mathrm{~mm}$ long; and the small capsules and seeds typical of this genus. The thick leaf, which usually reaches $5-7 \mathrm{~mm}$ in cross-section in mature fresh plants, is one of the best diagnostic characters of the species, that differentiate it from G. calcarata, the latter showing a much thinner leaf up to $2.5 \mathrm{~mm}$ wide. However, this character can be confusing when working with herbarium material, in which leaf width decreases considerably in dry plants. It is also important to disregard young, immature plants of G. anomala in which leaves can be also thin.

The illustration and description of $G$. anomala, obtained from cultivated material in London, shows bulbs lacking a distinct neck or cataphylls, matching some wild populations. However, it is also common that the bulb neck bears 
brown, papery cataphylls clasping the leaf base (MacOwan 1853 GRA!; Dyer 358 GRA!; Barker 5012 GRA!; Galpin 6293 BOL!; among others), and some populations show transversal dark markings, which range from scarcely evident (Paterson 2648 GRA!; Dold 16011 GRA!; Dold 16042 GRA!; Dold 16050 GRA!; Dold 16055 GRA!) to obvious (Dold 16018 GRA!), giving a zebra-banding pattern resembling that present in other Hyacinthaceae species, such as Albuca bakeri Mart.-Azorín \& M.B. Crespo in Martínez-Azorín et al. (2011c: 12), Coilonox zebrinum (Baker 1904: 92) Speta (2001: 176) and Rhadamanthus fasciatus Nordenstam (1970: 174), among others.

Several collections showing plain brown rather than distinctly barred cataphylls in combination with usually white flowers (Cruden 195 GRA!; Bayliss 3082 PRE0051144!; Dyer 358 GRA!; Dyer 1206 GRA!; MacOwan 1853 GRA!; Paterson 2648 GRA!; Rattray 829 GRA!; Stayner 58 GRA!; Barker 5066 NBG73272!; Barker 7127 NBG72493!) were named Urginea cataphyllata in scheda by A.A. Obermeyer. We were not able to find reliable characters to differentiate these populations from G. anomala, and therefore we follow Manning \& Goldblatt (2018) in placing this informal name in synonymy.

Peduncle of the inflorescence is commonly smooth, but in some populations they show papillae from minute and very scarce (Dold 16011 GRA!; Dold 16042 GRA!) to distinct and abundant (Johnson 167 GRA!; Dold 16055 GRA!), which sometimes co-occur with barred cataphylls; however, these characters appear to be random.

Inflorescence is usually a long raceme with many flowers, and pedicels commonly reach 4-6 $\mathrm{mm}$ in length, but in some populations around Willowmore and Steytlerville pedicels gradually lengthen to ca. 9-10 mm (Barker 5066 NBG73272!; Barker 7127 NBG72493! and Bayer s.n. NBG140530!) in combination with whitish flowers, papery whitish cataphylls surrounding the bulb neck and leaves are absent at the anthesis.

Flowers are also variable in colour and size: tepals are yellow, green, white or pinkish, with a discrete green, brown or purple stripe in the middle; they vary from $4-6 \mathrm{~mm}$ long, usually connate for $0.5-1 \mathrm{~mm}$. Stamens are spreading, never connivent to the style, but their length varies from 2 to $4 \mathrm{~mm}$. Gynoecium includes an ovoid-oblong ovary and a columnar, erect, style, but its size is also slightly variable.

Urginea eriospermoides Baker (1887: 126) was described from material sent by MacOwan and cultivated at Kew. Baker considered this species to differ from $O$. anomalum in its two, synanthous, terete leaves, only one fully developed, and in the whitish perianth with a broad, brown keel. However, the study of the holotype (K000257355!) revealed no differences with respect to the typical G. anomala, and the presence of two leaves per bulb can be regarded as due to cultivation conditions, a character also observed occasionally in nature. The whitish colour of flowers, as commented above, is also considered as part of the intraspecific variability.

At present, we were not able to find discrete patterns supporting the recognition of different taxa within the studied populations, although further morphological studies using living material and genetic analyses are needed to better understand this group of plants. This may facilitate the recognition of different taxa within this species complex. The considerable morphological variation observed in the current circumscription of $G$. anomala includes narrow to thicker leaves, which are synanthous or proteranthous; smooth to papillate base of peduncle; short to relatively long flower pedicels; and diverse colour and size of flower portions. This morphological variability may be due to either introgression among different ancient taxa co-occuring in the center of diversity of the genus (eastern Western Cape Province and western Eastern Cape Province), or to recent diversification within the group.

Studied materials:- SOUTH AFRICA. Western Cape. Victoria West (3123): in lapidosis prope Murraysburg (DD), elev. 4000 feet, October 1879 (in flower), W. Tyson 165 (BOL!); Merweville (3221): Beaufort West District, Layton Flats, Springbok camp (-BB), elev. 3000 feet, 22 December 1985 (in flower), D.A.M.B. Shearing 1173 (PRE0713551!); Beaufort West (3222): Beaufort West, Karoo National Park, Klipspringer Pass (-AD), elev. 1182 m, 6 December 2005 (in flower), A.C. Mudau 21 (NBG0210548-0!; PRE659249!); Beaufort West (3222): Stolshock, Karoo National Park (-AD/BC), elev. 900 m, 22 November 1988 (in flower), P. Bruyns 3423 (BOL61281!); Montagu (3320): Laingsburg, ca. $18 \mathrm{~km}$ south of Laingsburg on R323 (-BD), elev. 759 m, 3 October 2015 (in leaf), M. MartinezAzorin, M. Pinter, M.B. Crespo \& M.A. Alonso MMA1343 (ABH74913!); Montagu (3320): Barrydale (-DC), in flower, P.L. Perry 929 (NBG!); Oudtshoorn (3322): in collibus lapidosis prope Prince Albert (-AA), elev. 3000 feet, December 1904 (in flower and fruit), H. Bolus 11655 (BOL109653!); Oudtshoorn (3322): Klaarstroom, Koppieskraal (-BA), elev. 850 m, 13 December 2001 (in flower), P.V. Bruyns 8969 (NBG0200125-0!); Oudtshoorn (3322): near De Rust (-BC), October 1980 (in flower), Mauve, Reid \& Wikner 151 (PRE0611288!); Oudtshoorn (3322): Meiringspoort (-BC), 5 December 1985 (in flower), bulbs and leaves ex hort 13 March 1986, P.L. Perry 3410 (NBG140545!); Willowmore (3323): Approximately $7 \mathrm{~km}$ East of Uniondale towards Baviaanskloof (-CA), 29 September 1980 (in leaf) flowers ex hort 13 March 1986 and 9 December 1986, P.L. Perry 1444 (NBG140513!; PRE728897!); Willowmore (3323): Uniondale Division, Hills near Avontuur (-CA), elev. 3000 feet, January 1923 (in flower), H.G. Fourcade 2490 (BOL!); Willowmore (3323): Uniondale Division, Hills from Nuigund to Spitzkop (-CC), elev. 2700 feet, December 1928 (in 
flower), H.G. Fourcade 4251B (BOL61280!); Knysna (3423): Knysna, Plettenberg Bay (-AB), 26 February 1955, E.E. Esterhuysen 24210 (PRE0051074!; BOL61296! two sheets). Eastern Cape. Steynsburg (3125): Middleburg, Bangor farm (-AC), elev. 4000 feet, December 1917 (in flower and fruit), H. Bolus 14107 (BOL105687!); Steynsburg (3125): Middleburg Division, Rooispruit (-AD), 24 December 1951 (in flower), E. Esterhuysen 19697 (BOL61285!); Graaff Reinet (3224): in declivivus monte Cabe prope Graaff Reinet (-AD), elev. 3000 feet, December 1905 (in flower), $H$. Bolus 12401 (BOL!); Graaff Reinet (3224): Graaff Reinet C.P., near Graaff Reinet (-BA/BC), 2 December 1950 (in flower), W.F. Barker 7096 (NBG72473!); Graaff Reinet (3224): Ebenezer Farm, 27 km south-west of Pearston on R337, rocky hill behind (west) of farm dwellings (-DB), elevation $686 \mathrm{~m}$, December 2018 (in flower ex hort.), A.P.Dold 16048 (GRA!); Somerset East (3225): Welgedacht, west, north-west Cradock (-AB), 24 December 1980 (in flower ex hort), P. Bruyns 1582 (NBG123652!); Somerset East (3225): Pearston commonage, roadside veld (-CA), elevation 710 m, 23 October 2018 (in flower and fruit ex hort.), A.P.Dold 16022 (GRA!); Somerset East (3225): Somerset East Dist., near Charlton Falls, Boschberg (-DA), elev. 1200 m, 11 December 2008 (in flower), V.R. Clark \& J. Le Roux 491 (NBG0249515-0!); Somerset East (3225): $1.5 \mathrm{~km} \mathrm{SE}$ of Somerset East, just before turn off ro R335 (-DA), elev. 715 m, 12 October 2011 (in leaf), M Martínez-Azorín \& A.P. Dold MMA1000 (ABH59357!); Somerset East (3225): In arenosis campis pr. Somerset East (-DA), elev. 2500 feet, November-December (in flower), MacOwan 1853 (GRA!); Somerset East (3225): Somerset East district, prope Cookhouse (-DB), January 1902 (in flower), Kensit s.n. sub BH31827 (BOL105667!); Fort Beaufort (3226): Bedford (-CA), J. Erens 2209 (PRE0051150!); Fort Beaufort (3226): $22 \mathrm{~km}$ south of Bedford on R350, Normandale Farm, ca. $160 \mathrm{~m}$ SE from farmhouse (-CC), elevation $649 \mathrm{~m}, 8$ December 2018 (in flower and fruit), A.P.Dold 16047 (GRA!); Fort Beaufort (3226): Stockenstroom C.P., Fort Armstrong, Balfour (-DA), 6 January 1950 (in flower), B. Martin 147 (NBG72469!); Stutterheim (3227): Keiskamma Hoek - Red Hill (CA), December 1921 (in flower), F.J. Stayner 58 (GRA!); Stutterheim (3227): King William's Town (-CD), elev. 1500 feet, November 1893 (in flower), T.R. Sim 1721 (PRE0051140!); Stutterheim (3227): Kei River bridge, near Komgha (-DB), elev. 1800 feet, December 1891, H.G. Flanagan 1178 (PRE0051154!; BOL61291!); Butterworth (3228): Butterworth, Hospital Hill (-AC), December 1931 (in flower and fruit), A. Pegler 1801 (BOL61290!, PRE051153!); Willowmore (3323): 20 miles N of Willowmore (-AB), 3 December 1950 (in flower), W.F. Barker 7127 (NBG72493!); Willowmore (3323): Georgida (-AD), 1984 (in leaf), in flower ex hort Karoo NBG November 1985 (in flower), M.B. Bayer s.n. (NBG140530!); Willowmore (3323): Willowmore C.P., Miller (-BD), 5 December 1947 (in flower), W.F. Barker 5012 (NBG72471!); Willowmore (3323): Willowmore, NE Luiskraal homestead, Maraisdal, Joubertina (-DA), elev. 400 m, ex hort Karoo NBG, J.A. Forrester 400 (NBG140528!); Willowmore (3323): Uniondale, Die Hoek, N foot of Tsitzikamma mts. near Joubertina (-DD), 25 December 1951 (in flower and fruit), E. Esterhuysen 18343 (BOL61293! three sheets); Steytlerville (3324): Steytlerville C.P., near Steytlerville (-AD), 3 December 1947 (in flower), R.H. Compton 20314 (NBG72470!); Steytlerville (3324): Steytlerville C.P., Springbok Vlakte (-BD), 2 December 1947 (in flower), W.F. Barker 5066 (NBG73272!); Steytlerville (3324): Humansdorp Division, Kromme River, E of Assegai Bosch (-CD), elev. 700 feet, January 1937 (in flower), H.G. Fourcade 3943 (BOL71491!); Steytlerville (3324): Eastern Cape, Baviaans Kloof, (-DA), elev. 1000 feet, 17 December 1977 (in flower), R.D.A. Bayliss 8285 (PRE0606290!); Steytlerville (3324): Kouga Dam (-DA), 19 November 2002 (in flower), E.J. Van Jaarsveld 17120 (GRA!); Port Elizabeth (3325): Addo National Park entrance, on R342 from Addo town to Paterson (-BC), elevation 144 m, 1 July 2017 (in flower), A.P. Dold 16049 (GRA!); Port Elizabeth (3325): Alexandria, foot of Zuurberg pass (-BC), elev. 800 feet, 17 December 1953 (in flower), E.E.A. Archibald 5460 (GRA!); Port Elizabeth (3325): Alexandria, Addo Nat. Park (-BD/DB), elev. 500 feet, 19 October 1951 (in leaf), E.E. Archibald 3743 (GRA!); Port Elizabeth (3325): Addo El. Nat. Park (-BD/DB), 18 December 1996 (in flower), K. Johnson 167 (GRA!); Port Elizabeth (3325): Alexandria, elev. 600 feet, 05 January 1956 (in flower), E.E.A Archibald 6154 (GRA!); Port Elizabeth (3325): Somerset East C.P., Ann's Villa, Zuurberg (-BD), elev. 2400 feet, 30 December 1965 (in flower), R.D. Bayliss 3114 (NBG82928!); Port Elizabeth (3325): turn off to Loeri Dam, off Hankey road (-CC), 31 May 2013 (in leaf ex hort.), 08 July 2013 (in flower ex hort), corresponding to WW02455 (ABH!); Port Elizabeth (3325): Sundays River (-DB), January 1932 (in flower), Harries s.n. sub NBG2604/29 (BOL61284!); Port Elizabeth (3325): Redhouse (-DC), December 1914 (in flower), T.V. Paterson 506 (PRE051152!; BOL71490!); Port Elizabeth (3325): Redhouse (-DC), November 1914 (in flower), T.V. Paterson 2648 s.n. (GRA!); Port Elizabeth (3325): Redhouse village, to the right (east) of main entrance to village between road and school (-DC), elevation $7 \mathrm{~m}, 7$ June 2017 (in flower and fruit), $A$. P. Dold 16018 (GRA!); Grahamstown (3326): roadside Kransdrift, between Hounslow and Kwandwe (-AB), elevation $598 \mathrm{~m}, 23$ July 2017 (in flower and fruit), A.P.Dold 16022 (GRA!); Grahamstown (3326): Alicedale (-AC), 24 January 1918 (in flower), F. Cruden 195 (GRA!); Grahamstown (3326): Table Farm, west of Grahamstown (-AD), elevation 793 m, 28 May 2017 (in flower and fruit), A.P.Dold 16011 (GRA!); Grahamstown (3326): Albany, near Grahamstown on stony kopie 1/2 mile past Hamilton Dam and at Stones Hill near Beacon (-AD), elev. 2000-2200 feet, December 1925 
(in flower and fruit), R.A. Dyer 358 (GRA!); Grahamstown (3326): Grahamstown, Cradock Road beyond aerodrome flats (-AD), elev. $650 \mathrm{~m}$, December 1982 (in flower), A. Jacot-Guillarmod 9153 (GRA!); Grahamstown (3326): Grahamstown, Mountain Drive, $20 \mathrm{~m}$ south of Vodacom tower at west end of Mountain Drive (-AD), elevation $752 \mathrm{~m}$, 28 May 2017 (in flower and fruit), A.P.Dold 16015 (GRA!); ibidem, 7 January 2019 (in fruit), A.P.Dold 16055 (GRA!); Grahamstown (3326): Mnt. tops, east side of Howison's Poort, Grahamstown (-AD), elev. 2000 feet, 16 December 1898, E.E. Galpin 3097 (PRE0051142!); Grahamstown (3326): Just S of Fort Brown on road towards Grahamstown (-BA), 7 November 1997 (in flower), D. Snijman 1641 (NBG759447!, NBG759448!); Grahamstown (3326): Fort Brown, Grahamstown District (-BA), elev. 750 m, November 1921 (in flower), H.W.R. Marloth 10872 (PRE0051155!); Grahamstown (3326): Fort Brown (-BA), 2 February 2008 (in flower), J.C. McMaster s.n. (NBG0263013-0!); Grahamstown (3326): Grahamstown (-BC), 30 December 1903 (in flower), M. Daly 730 (GRA!); Grahamstown (3326): Grahamstown, Hillsview road (-BC), elevation 587 m, 10 December 2018 (in flower), A.P.Dold 16046 (GRA!); Grahamstown (3326): Grahamstown, Mountain Drive, mountain bike track/ramps (-BC), elevation $686 \mathrm{~m}$, 4 January 2019 (in flower and fruit), A.P.Dold 16050 (GRA!); Grahamstown (3326): Turn off from R67 between Grahamstown - Port Alfred to Belmont Valley, open veld adjacent to farm school and church (-BC), elevation $501 \mathrm{~m}, 9$ December 2018 (in flower and fruit), A.P.Dold 16052 (GRA!); Grahamstown (3326): Grahamstown, Howieson's Poort (-BC), 18 January 2002 (in flower), J.C. Manning 2702 (NBG!); Grahamstown (3326): Grahamstown (-BC), January 1905 (in flower), M. Daly 849 (BOL61290!); Grahamstown (3326): Grahamstown (-BC), 30 December 1903 (in flower), $M$. Daly 729 (GRA!); Grahamstown (3326): Albany C.P., West of Frasers Camp (-BD), 30 November 1950 (in flower), W.F. Barker 7001 (NBG72476!); Grahamstown (3326): Albany C.P., 24 miles E of Grahamstown (-BD), 30 November 1950 (in flower), W.F. Barker 7015 (NBG72475!); Grahamstown (3326): Bathurst C.P., Trappes Valley (-BD), 11 January 1947 (in flower and fruit), R.H. Compton 19121 (NBG72477!); Grahamstown (3326): Bathurst District, Trappes Valley (-BD), 19 December 1965 (in flower), R.D.A. Bayliss 3082 (PRE0051144!); Grahamstown (3326): Alexandria, Ghio (-DA), elev. 200 feet, 24 March 1952 (in flower and fruit), E.E.A. Archibald 4197 (GRA!); Peddie (3327): Kaffir Drift (-AC), 20 July 1971 (in leaf), Jessop s.n. (GRA!); Peddie (3327): near Kaffir Drift Police Station (-AC), 240 m elevation, 21 December 1993 (in flower and fruit), P.B. Phillipson 4204 \& A.P. Dold (GRA!); Peddie (3327): Peddie Dist on Fish River Kaffir Drift outspan and Pont Reserve (-AC), elev. 280 m, 5 November 1993 (in flower), A.P. Dold \& A. Booi 496 (GRA!); Peddie (3327): East London C.P., Chalumna Conservancy (-BA), 29 November 1950 (in flower and fruit), W.F. Barker 6965 (NBG72472! two sheets); Peddie (3327): East London District, Kaysers mouth of Chalumna River (-BA), elev. 15 feet, 24 December 1901 (in flower and fruit), E.E. Galpin 6293 (BOL61287!); Peddie (3327): East London C.P., Buffalo Pass rock crevices (-BB), 28 November 1945 (in flower), R.H. Compton 17783 (NBG72468!).

\section{Geschollia brachyandra Mart.-Azorín, A.P. Dold \& M.B. Crespo sp. nov. (Fig. 4)}

Geschollia brachyandra resembles G. calcarata in the solitary narrow leaf, and elongated, multiflowered inflorescence, but the former differs in the leaf base surrounded by cataphylls which show dark, usually raised, transversal bars (not lacking zebrine cataphylls), the reddish flowers (not white), the tepals $3.2-4.2 \mathrm{~mm}$ long (not 4.5-5.3 mm long) with short and suberect filaments $1.4-1.9 \mathrm{~mm}$ long (not 2.5-4 mm long).

Type:-SOUTH AFRICA. Eastern Cape. Grahamstown (3326): 19 km from Grahamstown on Cradock road, Brakloof (now Brack Kloof), $500 \mathrm{~m}$ from turn-off onto farm drive, $20 \mathrm{~m}$ off of road verge (-AD), $690 \mathrm{~m}$ elevation, 27 November 1993 (in flower and fruit), A.P. Dold 438 (holotype GRA!).

Bulb hypogeal, solitary, ovate to subglobose, depressed in old plants, $12-35 \times 10-40 \mathrm{~mm}$, usually extended into a hypogeal neck to $6 \mathrm{~cm}$ long, covered with pale brown to greyish, membranous outer tunics and white fleshy tightly packed inner tunics. Roots fleshy, white, branched, $10-40 \times 0.7-1.5 \mathrm{~mm}$. Leaf solitary, terete, $8-35 \times 0.1-0.2 \mathrm{~cm}$, suberect, curved, glabrous, smooth, very slightly striate, usually withering from the tip showing transverse abscission plates, green, leathery, synanthous or proteranthous, surrounded at base by distinct zebrine cataphylls which show dark transversal bands that are commonly thickened and raised. Inflorescence 1 per bulb; raceme elongated, 5-18 cm long, erect, with 18-80 flowers; peduncle elongated, 12-25 cm long, greyish-green, erect, straight, smooth, sometimes minutely papillate at base; flower pedicels $1.5-3 \mathrm{~mm}$ long, patent to suberect at anthesis. Bracts lanceolate, acute, ca. $1 \mathrm{~mm}$ long, purplish, the lowermost with a broad, oblong spur ca. $2 \mathrm{~mm}$ long; bracteoles absent. Flowers pentacyclic, trimerous, stellate, erect-patent, flowering in the afternoon-evening. Flowers reddish-brown, campanulate with patent lobes, with a discrete red stripe along the middle of the perigone segments, evident on both sides. Tepals 6 , biseriate, shortly connate at the base for less than $1 \mathrm{~mm}$, erect at base and patent to slightly reflexed in the upper half, narrowly lanceolate-oblong, 3.2-4.2 × 1.2-1.8 mm, glandulous at apex. Stamens 6; filaments filiform, subfusiform, attenuate to 


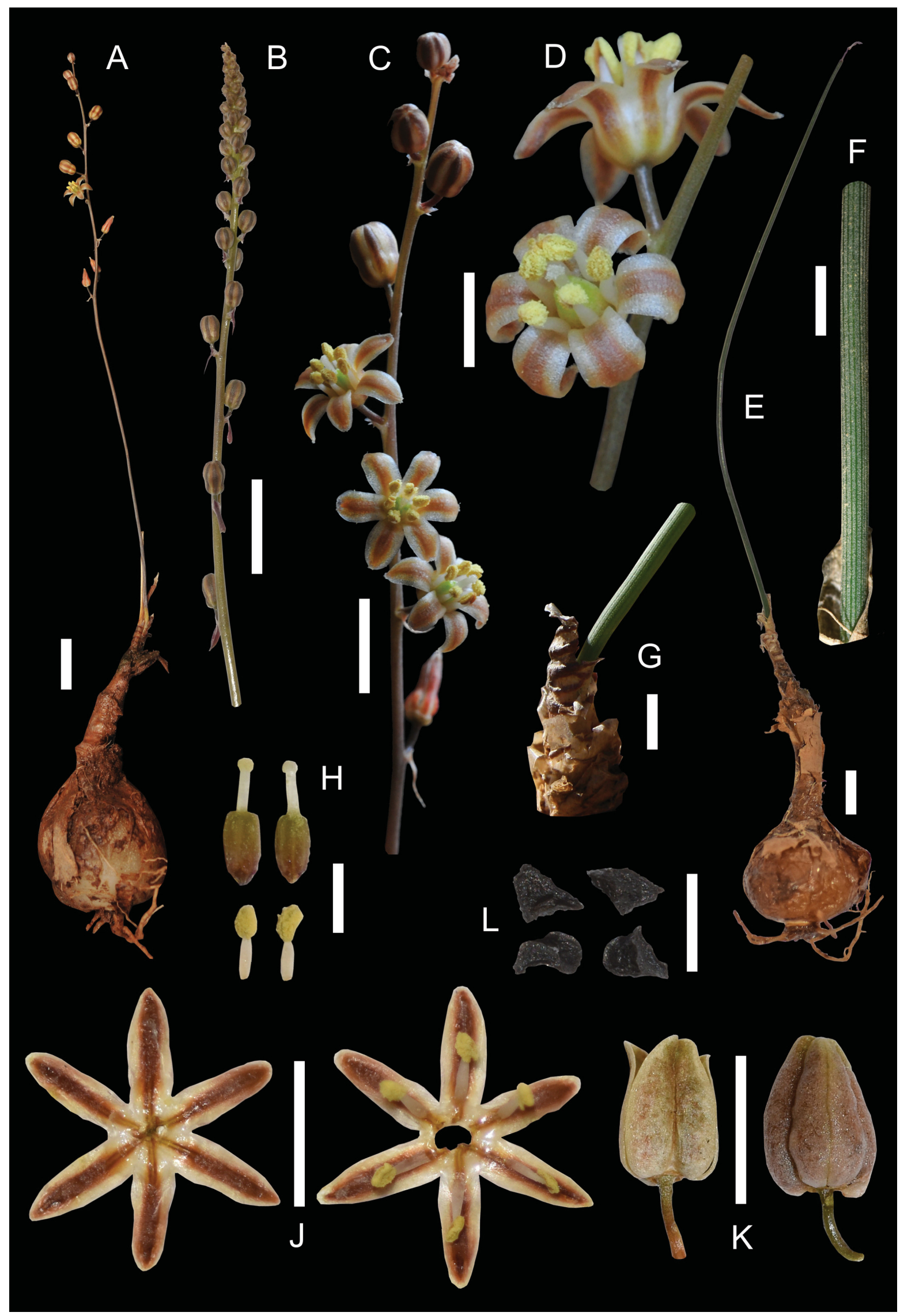

FIGURE 4. Geschollia brachyandra from the type locality. A. Plant in flower; B. Inflorescence with buds and spurred bracts; C. Inflorescence; D. Flowers, frontal and lateral views; E. Bulb and leaf; F. Leaf portion; G. Zebrine cataphylls and basal portion of leaf; H. Gynoecia and stamens. J. Dissected flower showing tepals and adnate filaments, righ dorsal view and left frontal view; K. Capsules, lateral view; L. Seeds. Scale bars: A, B, E: 1 cm; C, F, G, J, K: 5 mm; D, H, L: 2 mm. 
the apex, 1.4-1.9 mm long, mostly erect or slightly spreading, adnate to the base of tepals for less than $1 \mathrm{~mm}$, smooth; anthers yellow, oblong, ca. $0.8 \mathrm{~mm}$ long, dorsifixed, dehiscing along their whole length; pollen yellow. Ovary oblong, truncate to the style, 1.7-1.8 $\times 0.8-1 \mathrm{~mm}$, green; style white, thickened, columnar, 1.3-1.7 mm long, erect, trigonous in section; stigma three-lobed and papillose. Capsule ovate, trigonous, $3.8-4.2 \times 2.8-3.2 \mathrm{~mm}$, loculicidal, the 3 valves splitting to the base, with the withered perigone segments circumscissile below and forming an apical cap. Seeds polygonal or irregularly compressed, $1-1.5 \times 0.8-1 \mathrm{~mm}$, black, with wrinkled-rugose testa.

Etymology:-Named after the very short filaments, which are less than half the length of tepals.

Phenology:- Geschollia brachyandra flowers around October-November and fruits in December-January.

Habitat:-At a broad scale, the vegetation of the three known localities of G. brachyandra is mapped as Bhisho Thornveld in the Savanna Biome (Mucina \& Rutherford 2006). At a finer scale, the Subtropical Thicket Ecosystem Planning (STEP) Project mapped the localities as Grahamstown Grassland Thicket. This vegetation unit is described as a mosaic of low thicket $(2-3 \mathrm{~m})$ consisting of small bush clumps in a matrix of short $(0.1-1 \mathrm{~m})$ grassland vegetation. Fynbos elements occur within the grassland matrix on moist south-facing slopes. Many rare and localised endemic species occur in the grassland associated with this unit. Non-seasonal rainfall dominates the region with MAP between 376 and $696 \mathrm{~mm}$. The mean monthly maximum is $26.90^{\circ} \mathrm{C}$ in February and the mean monthly minimum is $6.96{ }^{\circ} \mathrm{C}$ in July (Vlok \& Euston-Brown 2002).

Distribution:-Geschollia brachyandra is only known from three localities northwest of Grahamstown, at Table Farm and Burntkraal farms, in the Eastern Cape Province in South Africa (Fig. 5). Further research is needed to more accurately establish the distribution range of this species.

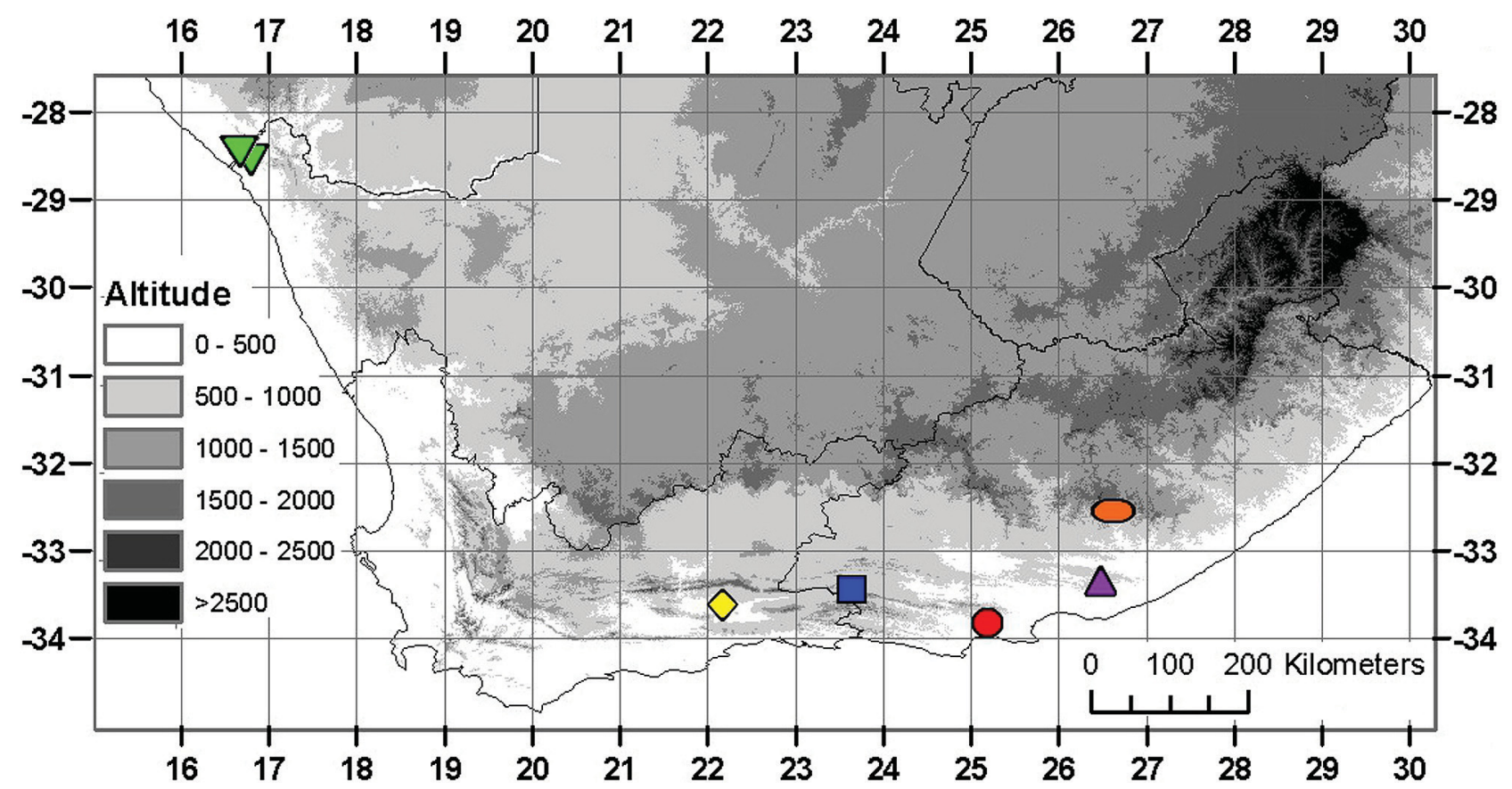

FIGURE 5. Distribution map of G. brachyandra (purple triangle), G. globuligera (red circle), G. longipedicellata (blue square), G. occultans (green inverted triangle), G. prolifera (orange ellipse) and G. zebrina (yellow diamond) in Southern Africa.

Diagnostic characters and taxonomic relationships:- G. brachyandra shows a unique combination of morphological characters, such as the hypogeal bulb with a neck surrounded by cataphylls which show dark, usually raised, transversal bars; the small reddish, campanulate flowers, with very short and suberect filaments of 1.4-1.9 $\mathrm{mm}$ long (less than half the length of tepals); and the small ovary (1.7-1.8 $\mathrm{mm}$ long) and style (1.3-1.7 $\mathrm{mm} \mathrm{long).} G$. calcarata approaches G. brachyandra in the solitary narrow leaf, and elongated, multiflowered inflorescence, but the former differs in the larger, white flowers, with filaments $2.5-4 \mathrm{~mm}$ long, about as long as the tepals; larger gynoecium; and leaf base not surrounded by distinct zebrine cataphylls.

Additional material studied (paratypes):- -SOUTH AFRICA. Eastern Cape. Grahamstown (3326): Table farm, $6.5 \mathrm{~km}$ from Pony Club, Grahamstown (-AD), $585 \mathrm{~m}$ elevation, 21 November 2017 (in flower), A.P. Dold 16024 (GRA!); Grahamstown (3326): Table Farm, $6.5 \mathrm{~km}$ from Grahamstown west, on Cradock road to Bedford, south side of road, $240 \mathrm{~m}$ from roadside (-AD), $587 \mathrm{~m}$ elevation, 07 October 2019 (in flower), A.P. Dold 16057 (GRA!); 
Grahamstown (3326): Burnt Kraal commonage, Grahamstown west, Abandoned clay-pigeon shooting range (-AD), 645 m elevation, 9 December 2018 (in flower), A.P. Dold 16051 (GRA!).

3. Geschollia calcarata (Baker) Mart.-Azorín, M.B. Crespo, A.P. Dold, M. Pinter \& Wetschnig comb. nov. $\equiv$ Ornithogalum calcaratum Baker (1874: 723), basionym. = Drimia calcarata (Baker) Stedje (1987: 663).

Type:- SOUTH AFRICA. Eastern District of Cape Colony, MacOwan s.n. Illustration by W.H. Fitch made from cultivated material sent by MacOwan to W. Saunders (lectotype designated by Stedje 1987): K!, (Fig. 6); epitype (designated here): Somerset East (3225): Somerset East District, near Charlton Falls, upriver on ledges on rock-outcrops/low cliffs between homestead and falls, Boschberg, (-DA), 1400 m elevation, 11 December 2008, V.R. Clark, R.J. Daniels, M. Fabricius \& J. Le Roux 487 (NBG0267388!).

Bulb hypogeal, solitary or rarely splitting, ovate to subglobose, slightly depressed in old plants, $12-23 \times 10-26 \mathrm{~mm}$, usually extended into a short hypogeal neck up to $1 \mathrm{~cm}$ long, with pale brown to greyish, membranous outer tunics and white fleshy tightly packed inner tunics. Roots fleshy, white, branched, $10-50 \times 0.7-1.5 \mathrm{~mm}$. Leaf solitary, terete, 5-21 $\times 0.10-0.25 \mathrm{~cm}$, suberect, curved, smooth, glabrous, very slightly striate with prominent longitudinal nerves, usually withering from the tip showing transverse abscission plates, green, leathery, usually synanthous. Inflorescence 1 per bulb, rarely 2; raceme elongated, 2-10 cm long, erect, with 8-30 flowers; peduncle elongated, 12-25 cm long, greyish-green, erect, straight, smooth; flower pedicels 4-6 mm long, patent to suberect at anthesis. Bracts lanceolate, acute, ca. $1 \mathrm{~mm}$ long, brownish, the lowermost with a long spur ca. 4-6 mm long; bracteoles absent. Flowers pentacyclic, trimerous, stellate, erect-patent, diurnal. Tepals 6, biseriate, white, with a discrete green stripe along the middle of the perigone segments, more evident on the abaxial side, slightly reflexed at full anthesis, shortly connate at the base for less than $1 \mathrm{~mm}$, narrowly lanceolate-oblong, 4.5-5.3 $\times 1-1.5 \mathrm{~mm}$, glandulous at apex. Stamens 6; filaments filiform, subfusiform, attenuate to the apex, 2.5-4 mm long, spreading, adnate to the base of the tepals for less than $1 \mathrm{~mm}$, smooth; anthers yellow, oblong, ca. $1 \mathrm{~mm}$ long, dorsifixed, dehiscing along their whole length; pollen yellow. Ovary ovate-oblong, truncate to the style, $1.5-2 \times 0.8-1.2 \mathrm{~mm}$, green, sometimes with white maculae along septal nectaries; style erect, white, thickened, columnar or rarely obtriangular, $1.5-2(-2.5) \mathrm{mm}$ long, trigonous in section; stigma three-lobed and papillose. Capsule ovate, trigonous, $4-4.5 \times 2.5-3 \mathrm{~mm}$, loculicidal, the 3 valves splitting to the base, with the withered perigone segments circumscissile below and forming an apical cap. Seeds polygonal or irregularly compressed, $1.2-2.1 \times 0.6-1.1 \mathrm{~mm}$, black, with wrinkled-rugose testa.

Etymology:- Named after the large spurs of the lowermost bracts.

Phenology:-Geschollia calcarata flowers at different times of the year, related to rainfall patterns, but mostly between September and March.

Habitat:- G. calcarata is found in diverse biomes, such as Albany Thicket, Fynbos, Grassland, Nama-Karoo, Savanna and Succulent Karoo (Mucina \& Rutherford 2006). Its populations range from coastal regions to high mountains and grow in a wide range of sandy to rocky soils.

Distribution:- G. calcarata is known from several localities in the Eastern Cape Province with some populations in the western regions of the Western Cape Province, and southern KwaZulu-Natal Province in South Africa, and Lesotho (Fig. 8).

Diagnostic characters and taxonomic relationships:-Ornithogalum calcaratum was described by Baker in 1874 based on cultivated plants sent to Kew. At that time, Peter MacOwan was based in Somerset East and it is probable that the material sent by MacOwan was collected in the vicinity of that town. Recent collections, Clark \& Le Roux 294 (NBG!) and Clark et al. 487 (NBG!) from the Boschberg (Somerset East), fit well with the original description and illustration (Fig. 6) of this species. A similar case regards Albuca tenuifolia Baker, a long overlooked species described by Baker in 1872 from material sent by MacOwan to Kew and illustrated from cultivated material, which was recently rediscovered at the Boschberg (Martínez-Azorín et al. 2011b, 2012), where both species co-occur on top of that mountain.

G. calcarata can be recognized by the solitary bulb (rarely splitting) with a single, terete, narrow leaf (to 2.5 $\mathrm{mm}$ wide in mature plants) and elongated peduncle and raceme together with the small capsules and seeds typical of the genus. However, our studies evidence a considerable variation in flower colour, morphology and size of tepals, filaments length and gynoecium size. Some populations from the Little Karoo, east of Calitzdorp (ABH74916) differ from typical plants in their styles being slightly longer than the ovary and obtriangular (Fig. 7). Other populations present brownish, papery cataphylls at the base of the leaf (Dold 612 GRA!). The species, as here circumscribed, covers different habitats, from coastal areas to elevated mountainous regions. The species is centered in the Eastern Cape Province of South Africa, but some disjunct populations are also found in the surroundings of Pietermaritzburg: Schlechter 3290 (BOL61283!, PRE0559667!, GRA!); Schlechter 3004 (GRA!); Moll 1850 (PRE0048648!); Martínez- 
Azorín et al. MMA1439 (ABH74241). Our genetic studies (Martínez-Azorín et al. in prep.) showed a considerable variability in the studied populations, which together with their diverse habitats and morphological variability indicate the need for further research.

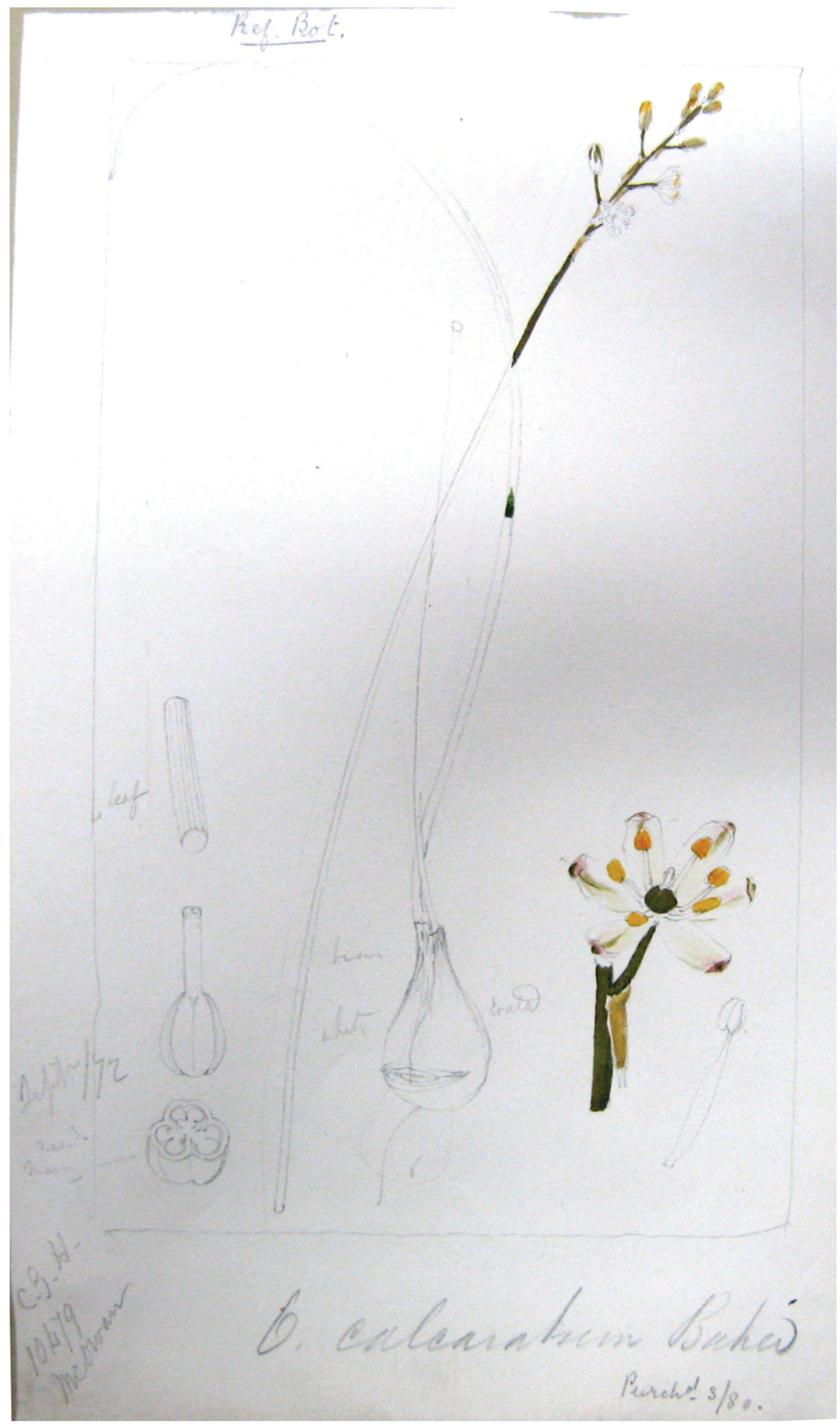

FIGURE 6. Lectotype of Ornithogalum calcaratum Baker. Reproduced with permission by Royal Botanic Gardens, Kew. 


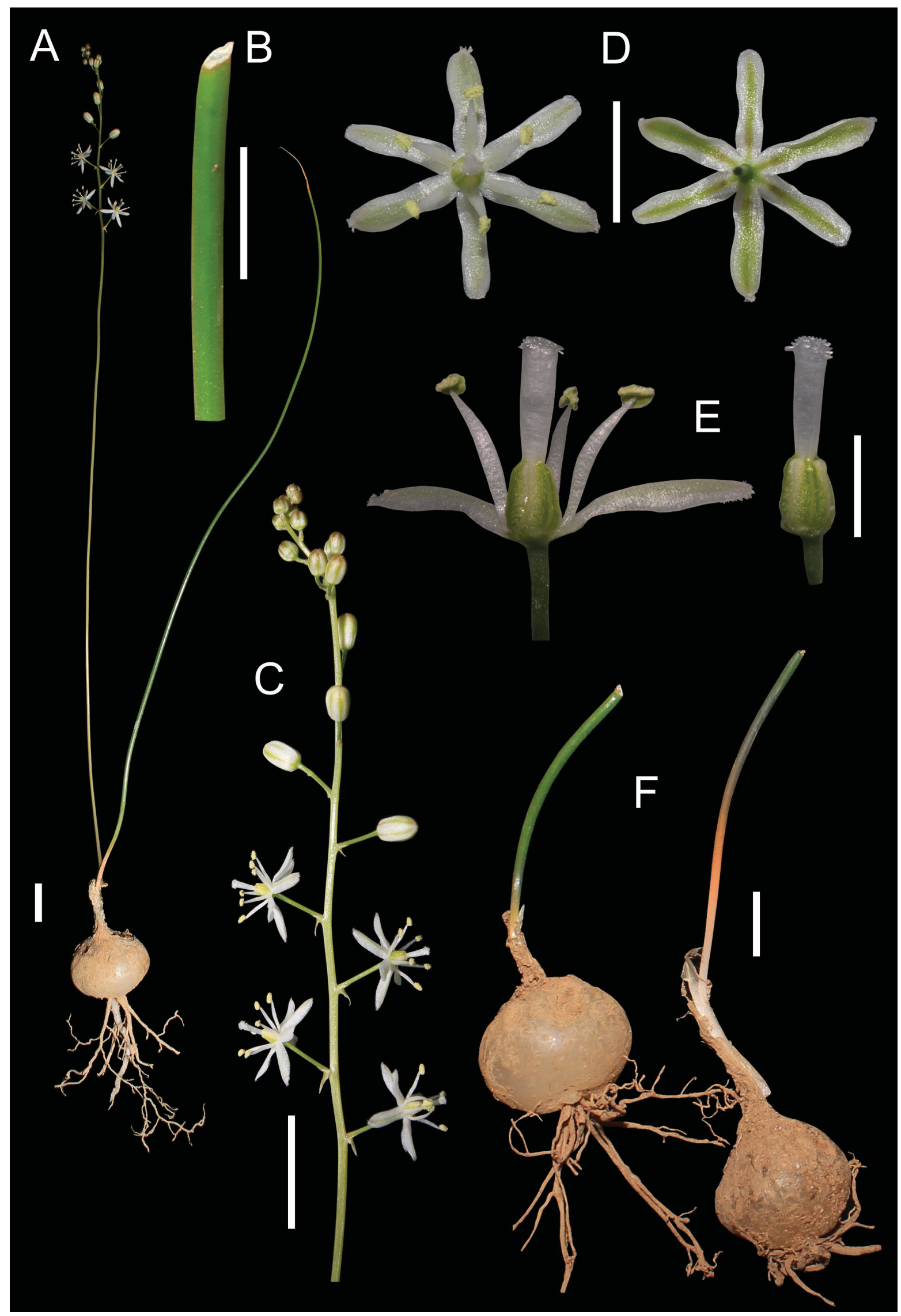

FIGURE 7. Geschollia calcarata from Redstone Hill Cottages, Little Karoo, South Africa. A. Plant in flower; B. Section of leaf; C. Inflorescence; D. Flowers, frontal and dorsal views; E. Dissected flower showing tepals, stamens and gynoecia; F. Bulbs with a single, terete leaf. Scale bars: A, C, F: $1 \mathrm{~cm}$; B, D: $5 \mathrm{~mm}$; E: $2 \mathrm{~mm}$. 


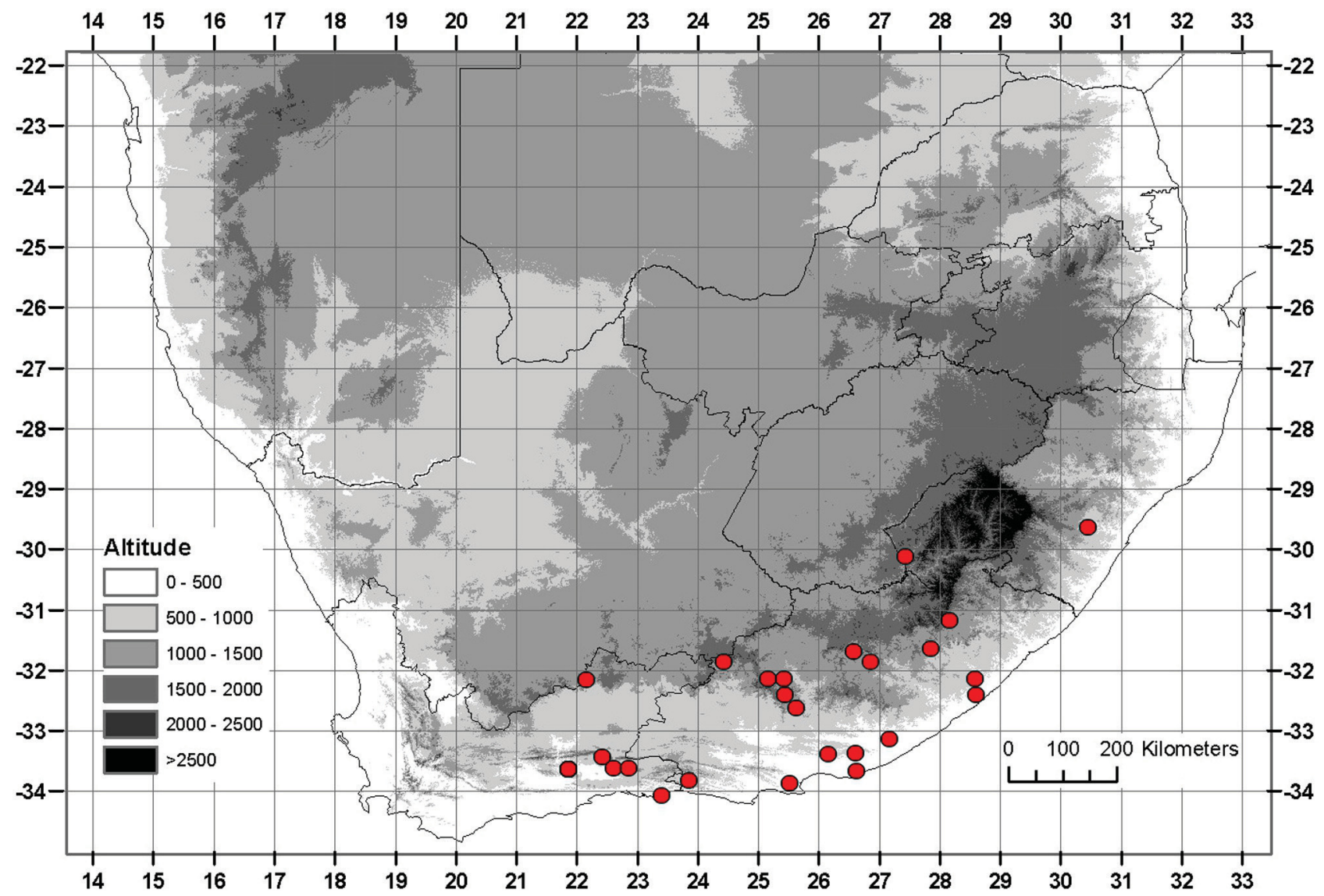

FIGURE 8. Distribution of studied material of Geschollia calcarata in South Africa.

Comments on other taxonomic treatments and current circumscription:- -Jessop (1977) included the name Ornithogalum calcaratum among nomina dubia citing "Type: not located and description inadequate. Probably a species of Drimia", but accepted a very broad concept of Drimia modesta (Baker 1892: 6) Jessop (1977: 302) including 13 heterotypic synonyms covering a large morphological variability and distribution in South Africa. Hilliard \& Burtt (1985), however, cited the illustration by Fitch as type and restricted the species concept to include only the name Urginea modesta Baker (1892: 6) from Pondoland, South Africa, as synonym. Stedje $(1987,1996)$ and Stedje \& Tulin (1995) also accepted Fitch's illustration as type and extended the distribution range of Drimia calcarata to East Africa, describing seeds from that area as 3-4 mm long. The most recent revision of Drimia sensu lato by Manning \& Goldblatt (2018) cites that "As circumscribed by Jessop (1977), Drimia calcarata included several taxa from the Cape Floristic Region that are now understood to be distinct species, namely $D$. dregei and $D$. salteri [...], D. hesperantha [...] and D. virens [...]". As Jessop (1977) considered Ornithogalum calcaratum as "nom. dub.", hence Manning \& Goldblatt (2018) refer rather to the very wide Drimia modesta concept of Jessop (1977). Furthermore, Manning \& Goldblatt (2018) follow previous authors in describing seeds of Drimia calcarata as 3-4 mm long, which is out of range for any known Geschollia species.

In summary, our circumscription of G. calcarata strongly differs from that adopted in recent revisions of Drimia s.l. Our studies, based on genetic analyses including several samples of Drimia modesta and related species (MartínezAzorín et al. in prep.), revealed that the taxa originally described from eastern South Africa (mostly KwaZulu-Natal and Gauteng Provinces) and synonymised by Jessop (1977) and later authors to Drimia modesta or Drimia calcarata, form a sister clade to Geschollia that differs in presenting several leaves per bulb, in combination with larger capsules and seeds. Accordingly, those names are not included in this account and will be treated in the revision of Urgineoideae (Martínez-Azorín et al. in prep.). In this treatment, G. calcarata is near-restricted to the Eastern Cape Province, with a few populations in southern KwaZulu-Natal and eastern Western Cape Provinces).

Additional material studied:-SOUTH AFRICA. Western Cape. Ladismith (3321): ca. $18 \mathrm{~km}$ east of Calitzdorp, Redstone Hill Cottages, above Buschman Cottage (-DB), 395 m elevation, 04 October 2015 (in leaf), M. MartínezAzorín, M. Pinter, M.B. Crespo \& M.A. Alonso MMA1346 (ABH74916!); ibidem, 30 June 2013 (in flower ex hort. in Graz, Austria), WW04904 (ABH!); ibidem, 07 July 2013 (in flower ex hort in Graz, Austria), WW04157 (ABH!); 
ibidem, 15 July 2013 (in flower ex hort. in Graz, Austria), WW03991 (ABH!); ibidem, 02 August 2013 (in flower ex hort. in Graz, Austria), WW04157 (ABH!); ibidem, 10 May 2015 (in leaf ex hort. in Graz, Austria), WW04157 (ABH!); Oudtshoorn (3322): southern foothills of Swartberg near Rust-en-Vrede (-AD), elevation 2100 feet, 26 December 1984 (in flower), J.H.J. Volk 883 (NBG131982!); Oudtshoorn (3322): Kammanassie Mountains, upper Diep Kloof (-DA), elevation 1220 m, 11 January 2001, E.G.H. Oliver \& I. Oliver 11843 (NBG!); Oudtshoorn (3322): Uniondale Division, Laudina (-DB), 8 March 1951 (in flower), E. Esterhuysen 18367 (BOL!); Willowmore (3323): Uniondale, Joubertina (-DD), ex hort at B.H. flowers January 1954, leaves August, Flower 5 March 1953, E. Esterhyusen 21242 (BOL61295!, BOL two sheets); Knysna (3423): Titzikama, Flats, Bitou River, Div. Knysna (-AB), 30 March 1910 (in flower), H.G. Fourcade 615 (BOL!, GRA!); Knysna (3423): Knysna Division, Plettenberg Bay (-AB), elevation 200 feet, 2 January 1934 (in flower), R.H. Compton 4674 (BOL61294!); Knysna (3423): Knysna, Plettenberg Bay (AB), on stony slope, 26 February 1955, E. Esterhuysen 24210 (PRE0051074!). Eastern Cape. Hanover (3124): Farm Houdebek 9, (Richmond-Nieu Bethesda region), Sneeuberg, NW of Compassberg (-CD), 1860 m elevation, V.R. Clark et al. 20 (NBG0213358!); Queenstown (3126): Andriesberg, near Bailey (-DA), elev. 5300 feet, 6 December 1896, E.E. Galpin 2233 (PRE0051147!; BOL71495!); Queenstown (3126): Queenstown, near Fincham's Nek (-DD), elev. 3450 feet, November 1896 (in flower), E. Galpin 2202 (BOL61292!); Lady Frere (3127): Transkei, hills near Engcobo (-DB), on dry cliffs, 12 October 1961 (in flower and fruit), E. Esterhyusen 29244 (BOL61286!); Umtata (3128): Maclear, foot of Pot River Pass (-AA), 30 November 2012, J.C. Manning 3401 (NBG277391!); Beaufort West (3222): Beaufort West, Karoon National Park, Brandewynsgat (-AA), elev. 1235 m, 7 December 2005 (in flower), A.C. Mudau $35 A$ (PRE0659258.0!); Somerset East (3225): Mountain Zebra National Park, Farm 413, Elandsfontein (-AA), elev. 1262 m, 13 December 2005 (in flower), A.C. Mudau 155 (PRE0659302.0!); Somerset East (3225): Mountain Zebra National Park, East of Doringhoek Dam, next to the road (-AB), elev. 1245 m, 12 December 2005 (in flower), A.C. Mudau 129 (PRE0659289.0!); Somerset East (3225): Mountain Zebra National Park, next to Doringhoek Dam (-AD), elev. 1284 m, 12 December 2005 (in flower), A.C. Mudau 109 (PRE0659278.0!); Somerset East (3225): Somerset East, Boschberg Nature Reserve, summit of Boschberg near Bloukop (-DA), 1550 m elevation, 5 December 2008, V.R. Clark \& J. Le Roux 294 (NBG0249514!); Butterworth (3228): Tsolorha, Mbashee River (-BA), 19 November 2002 (in flower), E.J. Van Jaarsveld 16902 (NBG0257549!); Butterworth (3228): Transkei, Gatyana/Willovale, Gatyana coast, Beechamwoods FD reserve, area between Shixini and Nqabara Rivers (-BC), 23-26 December 1993 (in flower and fruit), A.P. Dold 612 (GRA!); Port Elizabeth (3325): Bridgemead suburb, P.E., Parsons Vlei Farm (-CD), $175 \mathrm{~m}$ elevation, 8 December 1996, A.P. Dold 2507 \& M.Cocks (GRA!); Grahamstown (3326): Alexandria, Tootabi Rd. (AC), 13 January 1956 (in flower), E.E.A. Archibald 6172 (PRE0051149!); Grahamstown (3326): Grahamstown, above Rabbit's Wood (-BC), recently burnt grassveld, 28 April 1964 (in flower and fruit), J.P. Jessop 853 (GRA18693!); Grahamstown (3326): Alexandria, Bushman's River mouth (-DA), elevation 70-100 feet, 11 December 1953 (in flower and fruit), E.E.A. Archibald 5429 (GRA!, PRE0051156!); Grahamstown (3326): Alexandria, Bushman's River Poort Heights (-DA), elevation 600 feet, 5 January 1956 (in bud), E.E.A. Archibald 6136 (GRA!); Peddie (3327): Peddie (-AA), 11 January 1947 (in flower), F.M. Leighton 2646 (BOL!). KwaZulu-Natal. Pietermaritzburg (2930): pr. Maritzburg (-CB), elev. 2000 feet, 18 September 1893 (in flower), R. Schlechter 3290 (BOL61283!, PRE0559667!, GRA!); Pietermaritzburg (2930): Maritzburg (-CB), elev. 3000 feet, 20 September 1893 (in flower), R. Schlechter 3004 (GRA!); Pietermaritzburg (2930): Pietermaritzburg, Oribi Aerodrome (-CB), elev. 2400 feet, 17 August 1965 (in flower), E.J. Moll 1850 (PRE0048648!); Pietermaritzburg (2930): Pietermaritzburg, Marconi P1 to R103 (-CB), 699 m elevation, 15 October 2015 (in flower and fruit), M. Martínez-Azorín, M. Pinter, M.B. Crespo \& M.A. Alonso MMA1439 (ABH74241!). LESOTHO. Lady Frere (3027): Basutoland, Mohale's Hoek (-AB), 24-25 October 1946 (in flower and fruit), E: Esterhuysen 13217 (BOL! two sheets).

\section{Geschollia globuligera Mart.-Azorín, A.P. Dold \& M.B. Crespo sp. nov. (Fig. 9)}

Geschollia globuligera resembles G. zebrina in flower morphology based on the filaments with distinct retrorse papillae and the gynoecium morphology with long deflexed curved style, however the former differs in the bulbs composed by 10-12 loose, subglobose and shortly pedunculated scales (not compact), the lack of zebrine cataphylls surrounding the leaf base (present in the latter species) and the oblong, truncate ovary (not ovate and attenuate to the style).

Type:-SOUTH AFRICA. Eastern Cape. Port Elizabeth (3325): Port Elizabeth, Thornhill, Van Stadens Wildflower Reserve, West side of reserve on flats, $300 \mathrm{~m}$ to the east of river gorge (-CC), $230 \mathrm{~m}$ elevation, coarse sandy soil on flats, recently burnt Algoa Sandstone Fynbos, 20 January 2018 (in flower), A.P. Dold TD16029 (holotype: GRA!; isotype: ABH!).

Bulb hypogeal, 15-20 × 20-35 mm, composed of 6-12, loose, thickened, subglobose and shortly pedunculated scales, each 10-13 × 6-10 mm, lacking outer tunics. Roots fleshy, white, branched, 20-100 $\times 0.7-1 \mathrm{~mm}$. Leaf solitary terete, 


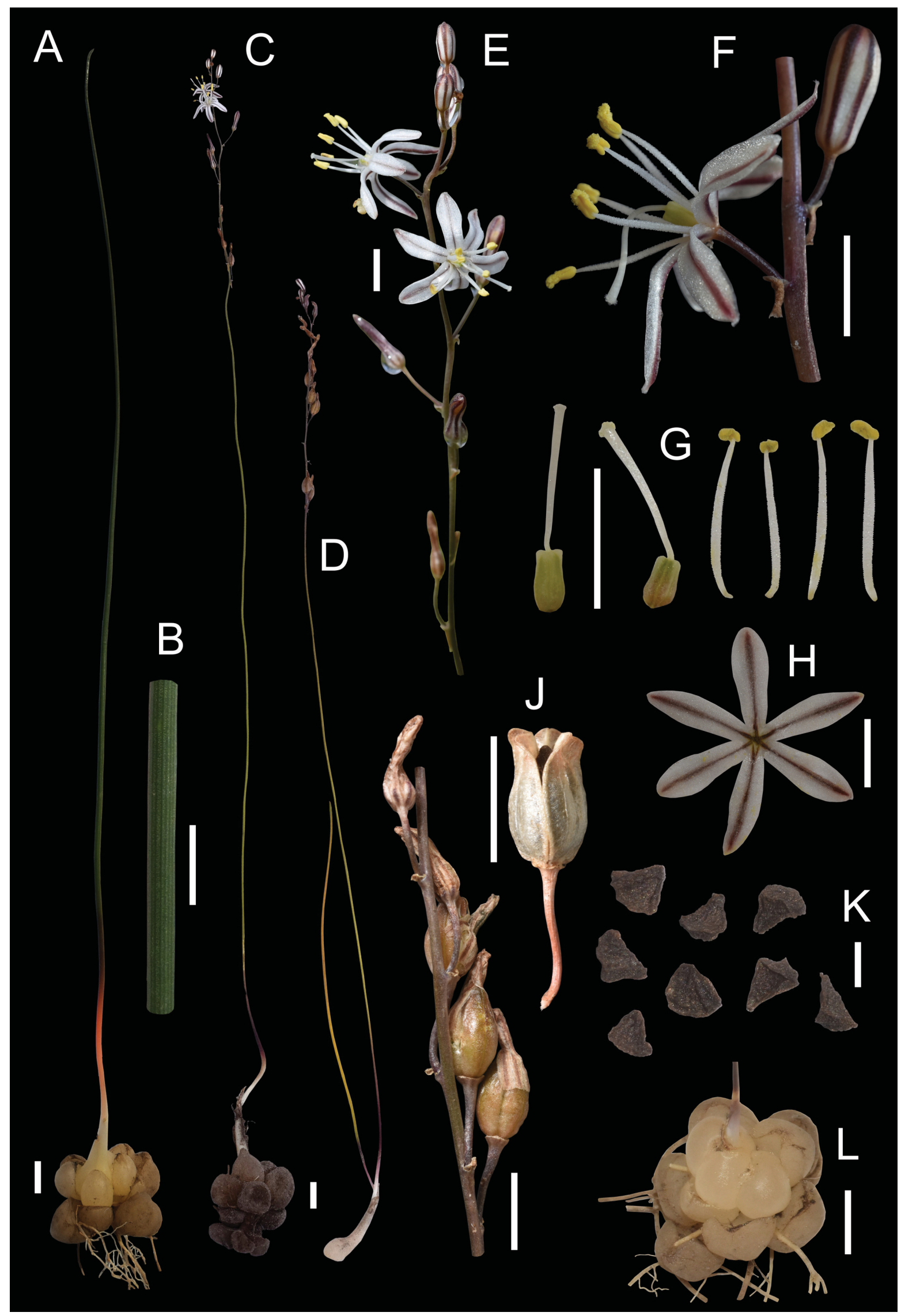

FIGURE 9. Geschollia globuligera from the type locality. A. Bulb with loose, globose, thickened scales and single terete leaf; B. Section of leaf; C. Plant in flower with withered leaf; D. Plant in fruit with withering leaf; E. Inflorescence; F. Detail of flower in lateral view showing micropapillate filaments and spurred bracts; G. Gynoecia and stamens; H. Tepals in frontal view; J. Dehisced capsule, lateral view; K. Polygonal, triangular seeds; L. Bulb with loose, subglobose scales. Scale bars: A, C, D, L: 1 cm; B, E-J: 5 mm; K: 1 mm. 
$15-32 \times 0.15-0.2 \mathrm{~cm}$, suberect, curved, smooth, glabrous, striate with longitudinal nerves, usually withering from the tip showing transverse abscission plates, green, reddish-purplish at base, leathery, withered or almost withered at flowering time. Inflorescence 1 per bulb; raceme elongated, 7-10 cm long, with 10-16 flowers, erect, with slightly sinuouse axes; peduncle elongated, 25-35 cm long, green to greyish, purple at base, erect, usually slightly sinuouse and sometimes with a distinct bent at base, smooth; flower pedicels 3-4 mm long at anthesis, patent to suberect, slightly elongating in fruit to 5-6 mm long and erect. Bracts lanceolate, acute, ca. $1 \mathrm{~mm}$ long, purplish, the lowermost with a spur ca. 1.5-2 mm long; bracteoles absent. Flowers pentacyclic, trimerous, stellate, erect-patent, flowering in the morning. Flowers white, with a distinct purplish stripe along the middle of the perigone segments, more evident on the abaxial side. Tepals 6 , biseriate, reflexed at full anthesis, shortly connate at base for ca. $1 \mathrm{~mm}$, lanceolate, $6.5-8 \times$ 1.8-3 mm. Stamens 6; filaments filiform, attenuate to the apex, 5.5-6 mm long, erect to slightly spreading, adnate to the base of the tepals for less than $1 \mathrm{~mm}$, covered by distinct retrorse elongated papillae along the upper $2 / 3$ of their length; anthers yellow, oblong, ca. $1.3 \mathrm{~mm}$ long, subbasifixed, dehiscing along their whole length; pollen yellow. Ovary oblong, truncate to the style, $1.9-2.3 \times 0.9-1.1 \mathrm{~mm}$, green with longitudinal white areas between septal nectaria; style white, narrowly columnar, 5-6 mm long, deflexed, trigonous in section; stigma slightly three-lobed and papillose. Capsule ovate, 5-6 $\times 2.5-3.2 \mathrm{~mm}$, trigonous, loculicidal, the 3 valves splitting to the base, with the withered perigone segments circumscissile below and forming an apical cap. Seeds numerous per locule, subtrigonous or subpolygonal and irregularly compressed, $1.1-1.7 \times 0.7-0.9 \mathrm{~mm}$, brownish black, with slightly tuberculate testa.

Etymology:-Named after the subglobose, loose, thickened bulb scales.

Phenology:-Geschollia globuligera flowers in January at the type locality, opening at dawn and closing about noon. The species seems to flower after fires.

Habitat:-This species occurs in fairly coarse sandy soil derived from Ordovician sandstones of the Table Mountain Group, on flats dominated by fynbos vegetation. The only known population occurs in Algoa Sandstone Fynbos vegetation. This area is characterized by rainfall throughout the year (mean annual precipitation $680 \mathrm{~mm}$ ) with a slight peak in March and October, with a mean annual temperature of $17^{\circ} \mathrm{C}$ and only three days of frost per year (Mucina \& Rutherford 2006).

Distribution:- G. globuligera is only known from the type locality in the Van Stadens Wildflower Reserve, west of Port Elizabeth in the Eastern Cape Province of South Africa (Fig. 5). Further research is needed to establish the distribution range of this species.

Diagnostic characters and taxonomic relationships:-G. globuligera is unique in the genus in having hypogeal bulbs composed by $10-12$, loose, subglobose and shortly pedunculated scales and the large flower with tepals $6.5-8$ $\mathrm{mm}$ long. Flower morphology of this species approaches G. zebrina, based on the filaments with distinct retrorse papillae and the long deflexed curved style. However, G. zebrina differs by the compact bulb, with a zebrine cataphyll surrounding the leaf, the smaller flower with tepals 5-6 mm long, and the ovary attenuate to the style, among other characters.

Additional material studied (paratypes):-SOUTH AFRICA. Eastern Cape. Port Elizabeth (3325): Van Staadens [sic], near Port Elizabeth (-CC), November 1909, T.V. Paterson 910 (GRA!).

\section{Geschollia longipedicellata Mart.-Azorín, Wetschnig, M. Pinter \& M.B. Crespo sp. nov. (Fig. 10)}

Geschollia longipedicellata can be recognized by the long pedicels $(20-25 \mathrm{~mm}$ long) combined with a solid, single bulb, single terete leaf, suberect stamens and slightly deflexed style being about twice the length of the ovary. All other species in the genus show pedicels up to $12 \mathrm{~mm}$ long and a different combination of characters.

Type:-SOUTH AFRICA. Eastern Cape. Willowmore (3323): Willowmore, ca. $1 \mathrm{~km}$ E of town (-BC), $860 \mathrm{~m}$ elevation, 4 May 2015 in flower ex hort in Graz Austria, W. Wetschnig \& C. Huber WW4944 (holotype: GRA!; isotype: ABH!).

Bulb hypogeal, solitary, ovate, 10-35 × 10-32 mm, extended into a very short epigeal neck up to $1 \mathrm{~cm}$ long, with pale grey-brown membranous outer tunics and white fleshy tightly packed inner scales. Roots fleshy, white, branched, $8-25 \times 1 \mathrm{~mm}$. Leaf solitary, terete, withered or almost withered at flowering time, aerial portion $10-20 \times 0.2 \mathrm{~cm}$, suberect, curved, green, smooth, glabrous, very slightly striate with prominent longitudinal nerves. Inflorescence long racemose, raceme 15-22 cm long, with 50-90 flowers; pedicels 20-25 mm long at anthesis, smooth, glabrous, subpatent; peduncle 18-25 cm long, erect, greyish, minutely papillose at basal portion; bracts ovate-lanceolate, small, 1-1.5 mm long, clasping the pedicels, spurred, the lowermost with a spur ca. $2 \mathrm{~mm}$ long, membranous, brownish. Flowers pentacyclic, trimerous, stellate, diurnal; tepals white on the adaxial side with a greenish longitudinal central band on the abaxial side, lanceolate-oblong, 4.5-5.5 $\times 1.6-1.8 \mathrm{~mm}$, free from the base or only connate for ca. $0.5 \mathrm{~mm}$ at base, strongly reflexed at anthesis exposing stamens and gynoecium, glandulous at apex, biseriate, outers slightly 


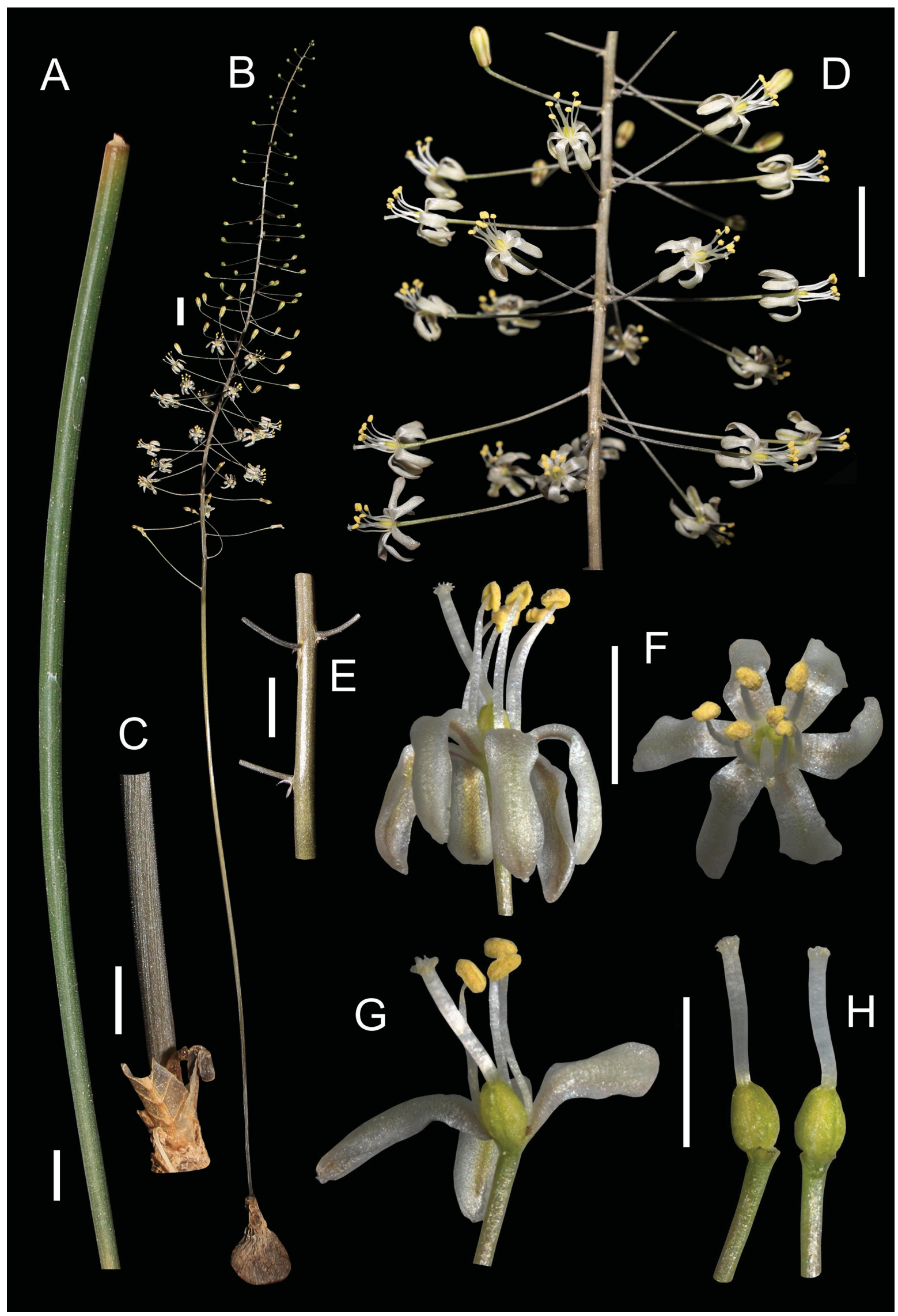

FIGURE 10. Geschollia longipedicellata from the type locality. A. Leaf; B. Plant in flower; C. Base of peduncle with micropapillae; D. Portion of inflorescence with long pedicels; E. Axis of inflorescence with spurred bracts; F. Flowers in lateral and frontal views; G. Dissected flower in lateral view showing stamens and gynoecium; H. Gynoecia in lateral views. Scale bars: B, D: $1 \mathrm{~cm}$; A, C, E: 5 mm; F-H: $3 \mathrm{~mm}$. 
overlapping inners at base, with recurved margins at anthesis. Stamens 6, suberect, shortly adnate to perigone for ca. $0.5 \mathrm{~mm}$; filaments white, terete, filiform, slightly curved, $4.5-5 \times 0.2 \mathrm{~mm}$, smooth; anthers yellow, oblong, ca. 1 $\mathrm{mm}$ long before dehiscence, dorsifixed, dehiscing by longitudinal slits, with yellow pollen. Ovary yellowish-green, ovate, contracted to the style, $1.3-1.6 \times 1 \mathrm{~mm}$; style white, columnar, $3.2-3.7 \mathrm{~mm}$ long, slightly deflexed and curved, trigonous in transversal section; stigma small and glandulose. Capsule and seeds not studied.

Etymology:-Named after the long flower pedicels at the anthesis, being unique in the genus.

Phenology:-Geschollia longipedicellata flowers around May in cultivation in Europe.

Habitat:- The only known locality of G. longipedicellata is located in the Succulent Karoo biome with SKv12 Willowmore Gwarrieveld vegetation. This species occurs in patches of open vegetation on rocky ground. This area is characterized by an aseasonal bimodal (autumn-spring) rainfall pattern (mean annual precipitation $250 \mathrm{~mm}$ ) with a slight optimum in March and from October to November, with a mean annual temperature of $16-17^{\circ} \mathrm{C}$ and fairly frequent frost (Mucina \& Rutherford 2006).

Distribution:- Only known from the type locality in the surroundings of Willowmore in the Eastern Cape Province of South Africa. Further studies are needed to evaluate the real distribution of this species.

Diagnostic characters and taxonomic relationships:-The single terete leaf of $G$. longipedicellata, together with its flower morphology place this species in Geschollia. Although no seeds are available at present, an important character for Geschollia identification, our phylogenetic studies (not shown) included a sample of this species from the type locality and confirmed its inclusion in this genus. No other species of Geschollia show such long flower pedicels. This character combined with its peculiar flower morphology, showing suberect stamens and slightly deflexed style (about twice the length of the ovary), support the description of this new species.

6. Geschollia occultans (G.Will.) Mart.-Azorín, M.B. Crespo \& M. Pinter comb. nov. $\equiv$ Drimia occultans G.Will. in Cact. Succ. J. (Los Angeles) 83(6): 287 (2012), basionym. (Fig. 11)

Type:-NAMIBIA. Oranjemund (2816): Southern Namib Desert, Swartkop Hill, 9 km E of Oranjemund (-DA), March 2011 ex hort. in Cape Town, G. Williamson 5922 (holotype: NBG0271283!).

Herbaceous deciduous geophyte. Bulb hypogeal, solitary, ovate to subglobose or sometimes depessed in old bulbs, 10-20 × 7-24 mm, extended into a hypogeal neck up to $25 \mathrm{~mm}$ long, with pale grey-brown membranous outer tunics and white fleshy tightly packed inner scales. Roots fleshy, white, branched, 10-30 × $1 \mathrm{~mm}$. Leaf solitary, terete, withered or almost withered at flowering time, aerial portion $2-4.5 \times 0.05-0.15 \mathrm{~cm}$, suberect, curved, green, smooth, glabrous. Inflorescence a short raceme 2-10 mm long, with 1-3 flowers; peduncle 20-50 mm long, erect, greyish, smooth; pedicels 2-4 mm long at anthesis, smooth, glabrous, spreading; bracts ovate-lanceolate, ca. $1 \mathrm{~mm}$ long, clasping the pedicels, spurred, the lowermost with a spur ca. $0.5 \mathrm{~mm}$ long, membranous, brownish. Flowers pentacyclic, trimerous, stellate, diurnal; tepals white on the adaxial side with a pale reddish-brown coloured longitudinal central band on the abaxial side, lanceolate-oblong, 5-6.5 $\times 1.4-1.8 \mathrm{~mm}$, glandulous at apex, biseriate, outers overlapping inners at base, almost free from the base or connate only for ca. $0.5 \mathrm{~mm}$ at base; with margins slightly recurved at anthesis. Stamens 6, suberect to spreading, shortly adnate to perigone for ca. $0.5 \mathrm{~mm}$; filaments white, terete, filiform or slightly fusiform, attenuate to the apex, $4.5-5.5 \times 0.2 \mathrm{~mm}$, smooth or minutely papillate; anthers yellow, oblong, ca. $1 \mathrm{~mm}$ long before dehiscence, dorsifixed, dehiscing by longitudinal slits, with yellow pollen. Ovary pale orange, ovate-oblong, somewhat truncate to the style, 2.2-2.5 × 1-1.3 $\mathrm{mm}$; style white, columnar, 1.9-2.2 $\mathrm{mm}$ long, erect, trigonous in transversal section; stigma small and slightly papillate. Capsule ovate, $4-4.5 \times 3.5 \mathrm{~mm}$, loculicidal, the 3 valves splitting to the base, with the withered perigone segments circumscissile below and forming an apical cap. Seeds narrowly triangular-pyramidal, 1.3-1.8 $\times 0.8-1 \mathrm{~mm}$, dark black, with rough texture.

Etymology:-Named after the difficulty of detecting the species due to its minute size and its hidden position amongst rocks (Williamson 2012).

Phenology:-Geschollia occultans flowers in late summer (March) in southern Africa. Flowers open towards late morning and wither the same day in the late afternoon (Williamson 2012).

Habitat:- G. occultans grows in sandy patches, sheltered between slabs of grey-blue to black metamorphosed schist covered in places by fine windblown sand, usually on southwestern aspects (Williamson 2012). Its populations are located in the Desert biome with Dn4 Western Gariep Lowland Desert. This area receives predominant winter rains (mean annual precipitation 45-60 $\mathrm{mm}$ ) with an estimation of 50-60 days of fog per year. Temperatures are generally relatively mild due to the cooling effect of the nearby Atlantic Ocean, but can be up to $48^{\circ} \mathrm{C}$ on berg-wind days, with no occurrence of frost. Winds and sand storms are frequent (Mucina \& Rutherford 2006). 


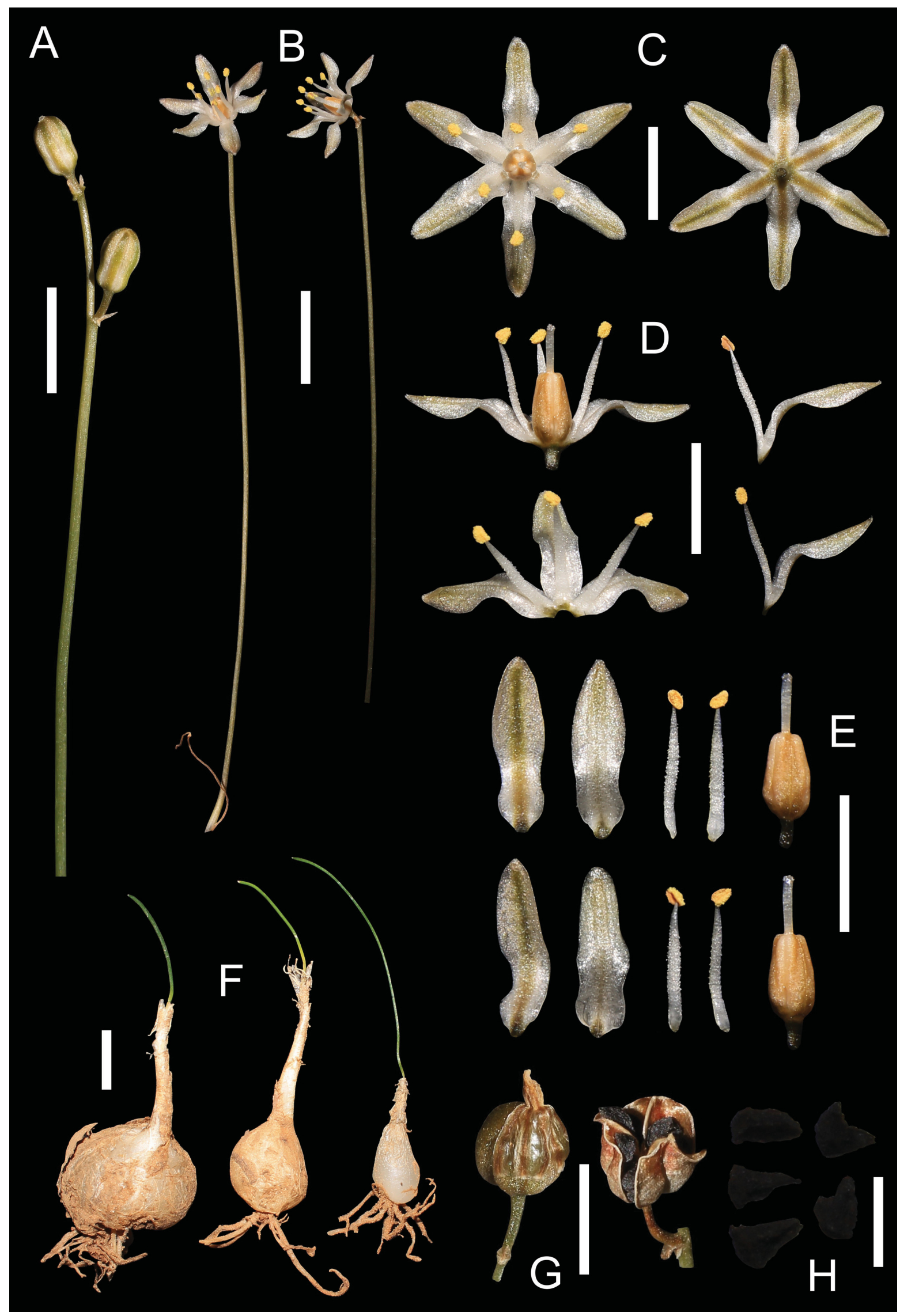

FIGURE 11. Geschollia occultans from E of Alexander Bay, South Africa. A. Inflorescence with buds and spurred bracts; B. Inflorescences with withered leaf; C. Flower, frontal and dorsal views, showing nectar drops; D. Dissected flower in lateral view showing stamens and gynoecium and tepals with shortly adnate filaments; E. Tepals, stamens and gynoecia, lateral views; F. Bulbs with single, terete leaf; G. Immature (left) and dehisced (right) capsules; H. Seeds. Scale bars: B, F: 1 cm; A, C-E, G: 5 mm; H: 2 mm. 
Distribution:- - G. occultans was described from a single population in southern Namibia. Our field work along the banks of the lower Orange River revealed three further populations that represent a first record of this species in South Africa (Fig. 5).

Diagnostic characters and taxonomic relationships:-G. occultans is characterized by the proteranthous, solitary, terete, short and thin leaf; the short raceme with few flowers; the comparatively large flowers in relation to plant and leaf size, and the narrowly triangular-pyramidal seeds. It shares the main diagnostic characters of Geschollia, such as the terete, single leaf, and small, polygonal seeds, but differs in size of leaves, size and morphology of flower organs, capsule and seed morphology, and in habitat and distribution. Moreover, our phylogenetic analyses included two samples of G. occultans from two populations, and confirmed their inclusion in Geschollia.

Additional material studied:- SOUTH AFRICA. Northern Cape. Oranjemund (2816): between Alexander Bay and Kuboes, rocky area overlooking bend of the Orange river (-BC), rock crevices filled with sand, $71 \mathrm{~m}$ elevation, 31 July 2016 in leaf, M. Martinez-Azorín, M.B. Crespo, M.A. Alonso, J.L. Villar, A. Vicente, J. Moreno \& A. Terrones MMA1582 (ABH 74363!); Oranjemund (2816): ca. $15 \mathrm{~km} \mathrm{E}$ of Alexander Bay on R382, koppie W of Grootderm (Spogplaas) farm house, $\mathrm{S}$ of road (-DA), rock crevices filled with sand, $20 \mathrm{~m}$ elevation, 31 July 2016 in leaf, $M$. Martinez-Azorín, M.B. Crespo, M.A. Alonso, J.L. Villar, A. Vicente, J. Moreno \& A. Terrones MMA1578 (ABH 74359!); ibidem, 17 July 2018 (in flower ex hort in Alicante, Spain), (ABH!); Oranjemund (2816): Spogplaas, ca. $8 \mathrm{~km} \mathrm{E} \mathrm{of}$ Alexander Bay Airport on road to Kuboes, slopes facing W near farm house (-DA), sandy soil on steep rocky slope, $61 \mathrm{~m}$ elevation, 26 August 2017 in leaf, M. Martinez-Azorín, M.B. Crespo, M.A. Alonso \& M. Pinter MMA1864 (ABH77049!).

\section{Geschollia prolifera Mart.-Azorín, A.P. Dold \& M.B. Crespo sp. nov. (Fig. 12)}

Geschollia prolifera resembles G. calcarata in leaf and flower morphology, but the former is easily identified by the proliferous, elongated and transversely constricted bulbs that form large clumps (not solitary) and the 2(-3) leaves per bulb (not single).

Type:-SOUTH AFRICA. Eastern Cape. Fort Beaufort (3226): Fort Fordyce Reserve, Fort Beaufort, East 'lip' of Fuller's Hoek forest basin, below EC Parks office and lodge (-DA), elevation 900 m, flowered ex hort 25 November 2017, A.P. Dold 16026 (holotype GRA!).

Bulb hypogeal, proliferous by bulb division and clump forming, narrow and distinctly elongated, commonly transversally constricted, single bulbs 30-40 × 10-13 mm, with pale brown to greyish membranous outer tunics and white fleshy, tightly packed inner tunics, usually extended into a short hypogeal neck up to $7 \mathrm{~mm}$ long surrounded by a single broad, acuminate, greyish cataphyll that sheaths leaves. Roots fleshy, white, branched, 10-90 $\times 0.5-1.8$ $\mathrm{mm}$. Leaves usually 2 per bulb, rarely 3 as a thin, small leaf, giving the appearance of bunches of leaves due to the proliferous nature of the bulbs, which soon produce leaves at early stages of bulb splitting with the resulting sister bulbs sharing the mother outer tunics, 5-30 $\times 0.08-0.2 \mathrm{~cm}$, terete, suberect, curved, smooth, glabrous, very slightly striate with prominent longitudinal nerves, usually withering from the tip showing transverse abscission plates, green, synanthous in cultivation. Inflorescence 1-2 per bulb; raceme 6-8 cm long, suberect to slightly bent, with 15-25 flowers; peduncle elongated, 13-17 cm long, suberect, curved, green, purplish at base, smooth; flower pedicels 4-5 $\mathrm{mm}$ long, patent at anthesis. Bracts lanceolate, acute, ca. $1 \mathrm{~mm}$ long, brownish, the lowermost with a spur ca. $1.5 \mathrm{~mm}$ long; bracteoles absent. Flowers pentacyclic, trimerous, stellate, erect-patent, diurnal. Tepals 6, biseriate, white, with a purplish longitudinal stripe along the middle on the abaxial side, reflexed at full anthesis, shortly connate at base for less than $1 \mathrm{~mm}$, narrowly lanceolate-oblong, 4.8-5.5 × 1.7-2 mm, glandulous at apex. Stamens 6; filaments filiform, subfusiform, attenuate to the apex, 2.3-2.8 mm long, spreading, adnate to the base of the tepals for less than $1 \mathrm{~mm}$, smooth; anthers yellow, oblong, ca. $0.8 \mathrm{~mm}$ long, dorsifixed, dehiscing along their whole length; pollen yellow. Ovary oblong, truncate to the style, $1.8-2 \times 0.9-1.1 \mathrm{~mm}$, green; style white, thickened, columnar, ca. $2 \times 0.5 \mathrm{~mm}$, erect, trigonous in section; stigma three-lobed and papillose. Capsule ovate, trigonous, $4.5-5.5 \times 3.5-4 \mathrm{~mm}$, loculicidal, the 3 valves splitting to the base, with the withered perigone segments circumscissile below and forming an apical cap. Seeds polygonal or irregularly compressed, sometimes elongated, $1.8-2.4(2.8) \times 0.8-1.4 \mathrm{~mm}$, black, with wrinkledrugose testa.

Etymology:-Named after the proliferous bulbs of this species, a distinct character not found in other known species in Geschollia.

Phenology:-Geschollia prolifera flowers in October-November, and fruits are produced in December-January.

Habitat:- This species grows on bare exposed sandstone rock sheets along edge of grassland bordering forest, sharing its habitat with many geophytes and succulents. The vegetation at the type locality is classified as Amathole Montane Grassland (Mucina \& Rutherford 2006). 


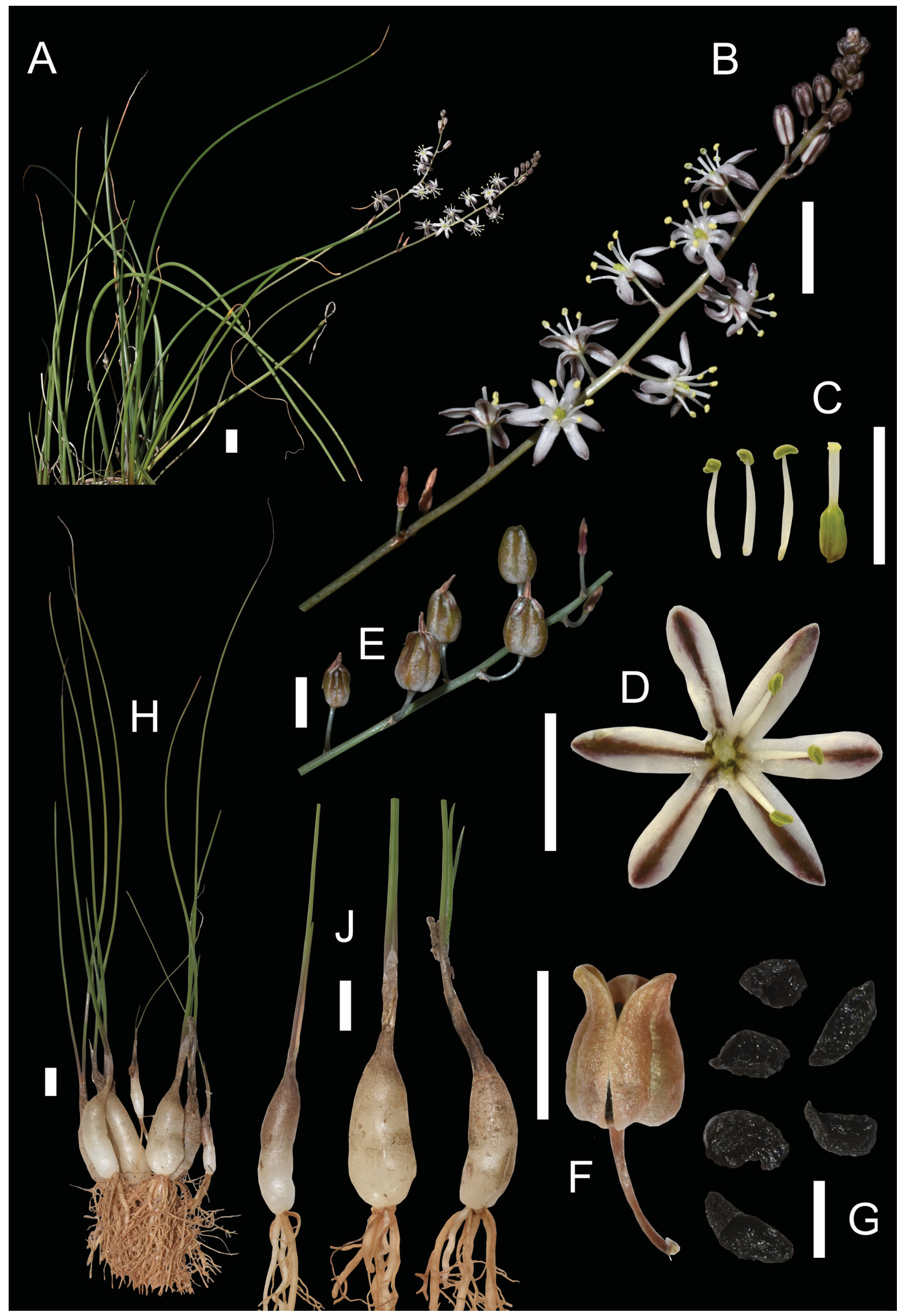

FIGURE 12. Geschollia prolifera from the type locality. A. Plants in flower; B. Inflorescence; C. Stamens and gynoecium; D. Dissected flowers, frontal view; E. Infructescence with immature capsules; F. Dehisced capsule; G. Seeds; H. Clump of bulbs with leaves; J. Bulbs with leaves. Scale bars: A, B, H, J: 1 cm; C, D, E, F: 5 mm; G: 2 mm. 
Distribution:- G. prolifera is only known from the type locality at Fort Fordyce Reserve, ca. $16 \mathrm{~km}$ NW of Fort Beaufort, in the Eastern Cape Province in South Africa (Fig. 5). Further research is needed to establish the distribution range of this species.

Diagnostic characters and taxonomic relationships:- - G. prolifera is easily identified by the proliferous bulbs and the 2(-3) leaves per bulb, giving the appearance of bunches of leaves and inflorescences. The single, terete leaf is one of the distinct characters defining Geschollia, although in some species such as G. anomala, a second leaf can be produced in cultivated plants. The typical presence of 2(-3) leaves per bulb in G. prolifera can be understood as a secondary adaptation linked to the proliferous nature of the bulbs, which produce leaves soon after splitting. The resultant sister bulbs share the mother bulb outer tunics. The inflorescence and flower morphology of G. prolifera approaches G. calcarata, but the latter species presents single bulbs and leaves, and never clumps.

\section{Geschollia zebrina Mart.-Azorín, A.P. Dold \& M.B. Crespo sp. nov. (Fig. 13)}

Geschollia zebrina resembles G. globuligera in flower morphology, both sharing filaments with retrorse elongated papillae and the deflexed and curved style, but the former differs by the compact bulb scales (not loose, globose, thickened and pedunculated), the presence of transversally-banded (zebrine) cataphylls surrounding the leaf base and the attenuate-ovate ovary (not truncated to the style).

Type:-SOUTH AFRICA. Western Cape. Oudtshoorn (3322): Grootkop Nature Reserve, NE of Oudtshoorn (-CA), 415 m elevation, 04 May 2015 in flower ex hort in Graz, Austria, M. Martínez-Azorín, J. Vlok, A.P. Dold \& A. Martínez-Soler MMA893 (holotype: GRA!; isotype: $\mathrm{ABH} !)$.

Herbaceous deciduous geophyte. Bulb hypogeal or only slightly epigeal in the upper portions and then photosynthetic, solitary, ovate, 20-50 $\times 8-20 \mathrm{~mm}$, sometimes extended into a short neck up to $1 \mathrm{~cm}$ long, with pale brown to greyish, slightly leathery outer tunics and white fleshy tightly packed inner tunics. Roots fleshy, white, branched, $8-50 \times 0.7-1$ $\mathrm{mm}$. Leaf solitary terete, $6-25 \times 0.08-0.15 \mathrm{~cm}$, suberect, curved, smooth, glabrous, very slightly striate with prominent longitudinal nerves, usually withering from the tip showing transverse abscission plates, green, leathery, withered or almost withered at flowering time, surrounded by a sheathing membranous zebrine cataphyll $20-50 \mathrm{~mm}$ long bearing transversally raised dark bands. Inflorescence 1 or rarely 2 per bulb; raceme elongated, 10-25 cm long, with 20-30 flowers, erect; peduncle elongated, 10-18 cm long, greyish, erect or slightly curved, smooth; flower pedicels 4-6 mm long, subpatent at anthesis. Bracts lanceolate, acute, ca. $1 \mathrm{~mm}$ long, purplish, the lowermost with a spur ca. $3 \mathrm{~mm}$ long; bracteoles absent. Flowers pentacyclic, trimerous, stellate, erect-patent, flowering in the afternoon-evening. Flowers white, with a discrete green stripe along the middle of the perigone segments, more evident on the abaxial side. Tepals 6, biseriate, strongly reflexed at full anthesis, shortly connate at base for ca. $1 \mathrm{~mm}$, lanceolate-oblong, 5-6 × 1.8-2.2 $\mathrm{mm}$. Stamens 6; filaments filiform, subfusiform, attenuate to the apex, 3-4 mm long, erect to slightly spreading, adnate to the base of the tepals for less than $1 \mathrm{~mm}$, coated by distinct retrorse elongated papillae along the upper $2 / 3$ of their length; anthers yellow, oblong, ca. $1 \mathrm{~mm}$ long, dorsifixed, dehiscing along their whole length; pollen yellow. Ovary ovate, attenuate to the style, $1.7-1.9 \times 0.8-0.9 \mathrm{~mm}$, pale orange; style white, narrowly columnar, 4-4.5 mm long, deflexed and curved at base, trigonous in section; stigma slightly three-lobed and papillose. Capsule and seed not studied.

Etymology:-Named after the distinct zebrine epigeal cataphyll that sheaths the base of the single terete leaf.

Phenology:-Geschollia zebrina flowers during May in cultivation in Europe.

Habitat:- This species occurs in patches of open succulent vegetation on stony ground where plants are sheltered by rocks. The only known population is located in the Little Karoo region with Eastern Little Karoo vegetation, characterized by an aseasonal rainfall (mean annual precipitation $290 \mathrm{~mm}$ ) with a slight optimum in March and pronounced decline in summer (December-January), with a mean annual temperature of $17^{\circ} \mathrm{C}$ and fairly frequent frost (Mucina \& Rutherford 2006).

Distribution:- G. zebrina is only known from the type locality, near Oudtshoorn in the Western Cape Province of South Africa (Fig. 5). Further research is needed to establish the distribution range of this species.

Diagnostic characters and taxonomic relationships:-G. zebrina is unique in the genus in having a zebrine, transversally-banded cataphyll together with filaments bearing distinct retrorse papillae, an ovate ovary and deflexed, curved style. Flower morphology of G. zebrina resembles that of G. globuligera based on the filaments with retrorse elongated papillae and the deflexed and curved style, pointing to a close relationship between these two species. However, G. globuligera clearly differs in its bulb with loose, globose and thickened pedunculated bulb scales, and the truncate ovary, among other characters. A sample of G. zebrina in our phylogenetic analyses (not shown) confirmed its inclusion in Geschollia. 


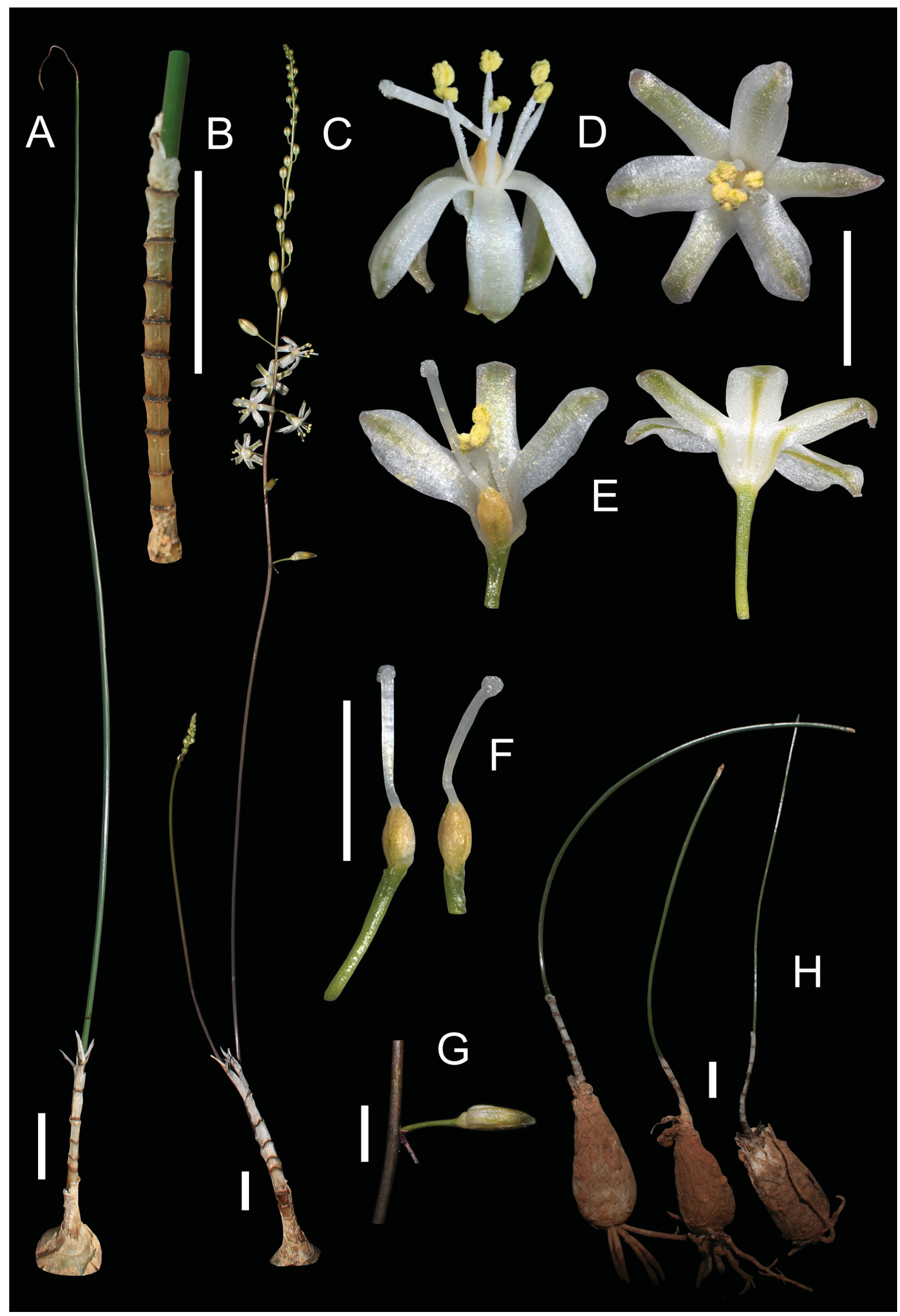

FIGURE 13. Geschollia zebrina from the type locality. A. Bulb with single, terete leaf; B. Zebrine cataphyll surrounding the base of the leaf; C. Plant in flower with a second emergent inflorescence and withered leaf; D. Flowers in lateral and frontal view showing papillate filaments; E. Developing flowers in lateral view, dissected on the left side; F. Gynoecia; G. Flower postanthesis with pedicel and spurred bract; H. Bulbs with a single terete leaf. Scale bars: A-C, H: $1 \mathrm{~cm}$; D-G: $5 \mathrm{~mm}$. 
Within Hyacinthaceae, the zebrine or transversally banded cataphyll is a recurrent character appearing in several species from different genera and subfamilies, such as Albuca annulata Mart.-Azorín \& M.B. Crespo in MartínezAzorín et al. (2011d: 696), A. bakeri, Coilonox zebrinum, Nicipe anguina (F.M. Leight. ex Obermeyer 1978: 356) Mart.-Azorín, M.B. Crespo \& Juan in Martínez-Azorín et al. (2011a: 31), N. monophylla (Baker 1897: 502) Mart.Azorín, M.B. Crespo \& Juan in Martínez-Azorín et al. (2011a: 32) and N. zebrinella (Müller-Doblies \& Müller-Doblies 1981: 87) Mart.-Azorín, M.B. Crespo \& Juan in Martínez-Azorín et al. (2011a: 32) (in subfamily Ornithogaloideae) or Geschollia brachyandra, Rhadamanthus fasciatus and most species of Tenicroa Rafinesque (1837: 52) (in subfamily Urgineoideae). The ecological adaptation of this character is uncertain, but it may be related to camouflage or aposematic signals of leaf bases against herbivores.

Additional material studied (paratype):-SOUTH AFRICA. Western Cape. Oudtshoorn (3322): Grootkop Nature Reserve, NE of Oudtshoorn (-CA), 415 m elevation, 28 September 2011 (in leaf), M. Martínez-Azorín, J. Vlok, A.P. Dold \& A. Martínez-Soler MMA893 (ABH59707!).

\section{Key to the species of Geschollia (based on living material)}

1. Bulbs elongated and proliferous, forming clumps; leaves $2(-3)$ per bulb ..... 7. G. prolifera Bulbs ovate-globose, not proliferous; leaf mostly solitary. 5. G. longipedicellata Pedicels of flowers 20-25 mm long. Pedicels of flowers up to $10 \mathrm{~mm}$ long.... Inflorescence very short, with 1-3 flowers ... 6. G. occultans

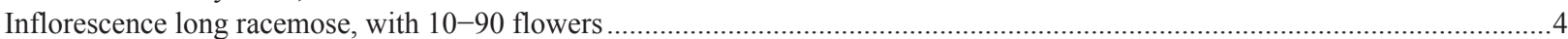

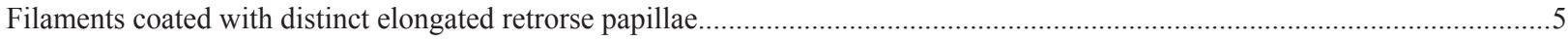

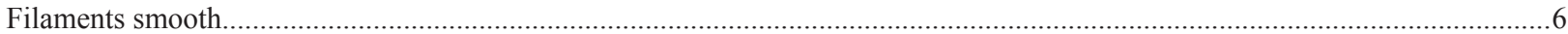
Tepals 5-6 mm long; bulb scales tightly imbricate; base of leaf surrounded by a transversally banded, zebrine cataphyll; ovary ovate, attenuate to the style 8. G. zebrina Tepals 6.5-8 mm long; bulb scales loose, subglobose and thickened; base of leaf not surrounded by a transversally banded, zebrine cataphyll; ovary oblong, truncate to the style.... 4. G. globuligera

6. Flowers small; tepals 3.2-4.2 mm long; filaments 1.4-1.9 mm long; leaf surrounded at base by cataphylls with distinct tranversal usually raised dark bars

2. G. brachyandra Flowers larger; tepals 4-6 mm long; filaments 2-4 mm long; leaf not surrounded by distinct transversally barred, raised cataphylls, sometimes showing weak transversal bandings 3. calcarata

\section{Acknowledgements}

This work was partly supported by H2020 Research and Innovation Staff Exchange Programme of the European Commission, project 645636: 'Insect-plant relationships: insights into biodiversity and new applications' (FlyHigh) and the grants ACIE18-03 and UAUSTI18-02 from University of Alicante. We thank the curators of the herbaria, who provided access to the specimens examined. We thank Ellie and Rudi Goossens for locating G. globuligera a century after its discovery at Van Stadens Wildflower Reserve. Ute and Dietrich Müller-Doblies are thanked for sharing vegetative material of Geschollia samples included in the phylogenetic analyses. Jan Vlok is thanked for his help in the field in the Little Karoo and for showing us some populations of Geschollia. Harry Smith and Anna Haigh (Royal Botanic Gardens, Kew) are thanked for providing information and digital images of type collections and drawings and for permission to reproduce the image of Ornithogalum calcaratum. All managers of Nature Reserves are thanked for allowing us access. The Department of Environment and Nature Conservation of Northern Cape Province (collecting and export permits numbers FLORA046/2010, FLORA047/2010, FLORA069/2011, FLORA070/2011, FLORA61/2/2015, FLORA61/2/2015, FLORA0057/2017, FLORA0058/2017) and CapeNature of Western Cape Province of South Africa (collecting and export permits numbers AAA008-00031-0028, 0027-AAA008-00699, 0028-AAA008-00203) provided permission to collect herbarium specimens to the first author and collaborators. The Ministry of Environment and Tourism of Namibia provided research/collecting permit (Permit number 2192/2016) and C. Mannheimer, S. Rugheimer and F. Chase kindly helped with field work in this country. 


\section{References}

Angiosperm Phylogeny Group (2003) An update of the Angiosperm Phylogeny Group classification for the orders and families of flowering plants: APG II. Botanical Journal of the Linnean Society 141: 399-436.

https://doi.org/10.1046/j.1095-8339.2003.t01-1-00158.x

Angiosperm Phylogeny Group (2009) An update of the Angiosperm Phylogeny Group Classification for the orders and families of flowering plants: APG III. Botanical Journal of the Linnean Society 161: 105-121. https://doi.org/10.1111/j.1095-8339.2009.00996.x

Angiosperm Phylogeny Group (2016) An update of the Angiosperm Phylogeny Group Classification for the orders and families of flowering plants: APG IV. Botanical Journal of the Linnean Society 181: 1-20.

https://doi.org/10.1111/boj.12385

Baker, J.G. (1870) Ornithogalum anomalum. Refugium botanicum vol. 3, t. 178.

Baker, J.G. (1873) Revision of the genera and species of Scilleae and Chlorogaleae. Journal of the Linnean Society, Botany 13: $209-292$. https://doi.org/10.1111/j.1095-8339.1872.tb00093.x

Baker, J.G. (1874) New Garden Plants [Ornithogalum calcaratum]. The Gardeners' Chronicle: a weekly illustrated journal of horticulture and allied subjects 1: 723-724.

Baker, J.G. (1887) New or noteworthy plants [Urginea eriospermoides]. The Gardeners' Chronicle: a weekly illustrated journal of horticulture and allied subjects, ser. 32 : 126.

Baker, J.G. (1892) Liliaceae novae Africae australis herbarii regii Berolinensis. Botanische Jahrbücher für Systematik 15: 4-8.

Baker, J.G. (1897) Liliaceae. In: Thiselton-Dyer, W.T. (ed.), Flora Capensis 6. Reeve and Co., London, pp. $253-525$.

Baker, J.G. (1904) The genus Albuca in the Herbarium of the Albany Museum, Grahamstown (with description of 14 new species). Records of the Albany Museum. Grahamstown 1: 89-94.

Bentham, G. \& Hooker, J.D. (1883) Genera plantarum vol. 3 pars II. Reeve \& Co. London, pp. 447-1258.

Chase, M.W., Reveal, J.L. \& Fay, M.F. (2009) A subfamilial classification for the expanded asparagalean families, Amaryllidaceae, Asparagaceae and Xanthorrhoeaceae. Botanical Journal of the Linnean Society 161: 132-136.

https://doi.org/10.1111/j.1095-8339.2009.00999.x

Compton, R.H. (1930) Novitates Africanae. Journal of Botany, British and Foreign. London 68: 102-107.

Crouch, N.R. \& Martínez-Azorín, M. (2015) Drimia edwardsii (Asparagaceae, Scilloideae), a new urgineoid species from the Mkhomazi River Valley of eastern South Africa. Phytotaxa 195: 135-144.

https://doi.org/10.11646/phytotaxa.195.2.2

Crouch, N.R., Martínez-Azorín, M., Crespo, M.B., Pinter, M. \& Alonso-Vargas, M.A. (2018) Zingela (Asparagaceae, Scilloideae), a distinct new urgineoid genus from KwaZulu-Natal, South Africa. Phytotaxa 371: 33-41.

https://doi.org/10.11646/phytotaxa.371.1.4

Dyer, R.A. (1951) Drimia anomala. Flowering plants of Africa 28: t. 1117.

Goldblatt, P., Manning, J.C. \& Forest, F. (2012) A review of chromosome cytology in Hyacinthaceae subfamilies Urgineoideae and Hyacinthoideae (tribes Hyacintheae, Massonieae, Pseudoprospereae) in sub-Saharan Africa. South African Journal of Botany 83 : $134-144$.

https://doi.org/10.1016/j.sajb.2012.07.023

Glen, H.F. \& Germishuizen, G. (2010) Botanical exploration of Southern Africa, ed. 2. Strelitzia 26. South African National Biodiversity Institute, Pretoria, 489 pp.

Gunn, M. \& Codd, L.E. (1981) Botanical Exploration of Southern Africa. A.A. Balkema, Cape Town, 400 pp.

Hilliard, O.M. \& Burtt, B.L. (1985) Notes on some plants of southern Africa chiefly from Natal XI. Notes from the Royal Botanic Gardens Edinburgh 42: 227-260.

IPNI (2019) The international plant names index. Available from http://www.ipni.org (accessed August 2019)

Jessop, J.P. (1977) Studies in the bulbous Liliaceae in South Africa 7. The Taxonomy of Drimia and certain allied genera. Journal of South African Botany 43(4): 265-319.

Leistner, O.A. \& Morris, J.W. (1976) Southern African place names. Annals of the Cape Provincial Museum 12: 1-565.

Manning, J.C. \& Goldblatt, P. (2018) Systematics of Drimia Jacq. (Hyacinthaceae: Urgineoideae) in southern Africa. South African National Biodiversity Institute, Pretoria, $173 \mathrm{pp}$.

Manning J.C., Goldblatt, P. \& Fay M.F. (2004) A revised generic synopsis of Hyacinthaceae in Sub-Saharan Africa, based on molecular evidence, including new combinations and the new tribe Pseudoprospereae. Edinburgh Journal of Botany 60: 533-568. https://doi.org/10.1017/S0960428603000404

Martínez-Azorín, M., Clark, V.R., Crespo, M.B., Dold, A.P. \& Barker, N.P. (2011b) The rediscovery of Albuca tenuifolia, an orophilous 
species from the eastern Great Escarpment in South Africa. Nordic Journal of Botany 29: 465-470.

https://doi.org/10.1111/j.1756-1051.2011.00944.x

Martínez-Azorín, M., Crespo, M.B., Alonso-Vargas, M.A., Dold, A.P., Crouch, N.R., Pfosser, M., Mucina L., Pinter, M. \& Wetschnig, W. (2019b) New combinations in the tribe Urgineeae (Asparagaceae subfam. Scilloideae) with comments on contrasting taxonomic treatments. Phytotaxa 397: 291-299.

https://doi.org/10.11646/phytotaxa.397.4.3

Martínez-Azorín, M., Crespo, M.B., Alonso-Vargas, M.A., Dold, A.P., Pinter, M. \& Wetschnig, W. (2018) Austronea (Asparagaceae, Scilloideae), a new genus from southern Africa, including the description of seven new species. Phytotaxa 365: 101-129. https://doi.org/10.11646/phytotaxa.365.2.1

Martínez-Azorín, M., Crespo, M.B. \& Dold, A.P. (2012) Albuca tenuifolia and Albuca shawii (Ornithogaloideae), two distinct species from South Africa. Bothalia 42: 193-196.

https://doi.org/10.4102/abc.v42i2.17

Martínez-Azorín, M., Crespo, M.B. \& Dold A.P. (2013a) Drimia cochlearis (Hyacinthaceae), a new species from South Africa. Systematic Botany 38: 332-338.

https://doi.org/10.1600/036364413X666831

Martínez-Azorín, M., Crespo, M.B., Dold, A.P. \& Barker, N. (2011c) The identity of Albuca caudata Jacq. (Hyacinthaceae) and a description of a new related species: A. bakeri. Phytokeys 5: 5-19.

https://doi.org/10.3897/phytokeys.5.1166

Martínez-Azorín, M., Crespo, M.B., Dold, A.P. \& Barker, N.P. (2011d) Albuca annulata sp. nov. (Hyacinthaceae) from the Albany Centre of Endemism, South Africa. Nordic Journal of Botany 29: 696-699.

https://doi.org/10.1111/j.1756-1051.2011.01178.x

Martínez-Azorín, M., Crespo, M.B., Dold, A.P., Wetschnig, W., Pinter, M., Pfosser, M. \& van Jaarsveld, E. (2013b) Sagittanthera (Hyacinthaceae, Urgineoideae), a new buzz pollinated genus from the Eastern Cape Province of South Africa. Phytotaxa 98(2): 43-54.

https://doi.org/10.11646/phytotaxa.98.2.2

Martínez-Azorín, M., Crespo, M.B. \& Juan, A. (2007) Taxonomic revision of Ornithogalum subg. Cathissa (Salisb.) Baker (Hyacinthaceae). Anales del Jardín Botánico de Madrid 64: 7-25.

https://doi.org/10.3989/ajbm.2007.v64.i1.47

Martínez-Azorín, M., Crespo, M.B. \& Juan, A. (2009) Taxonomic revision of Ornithogalum subg. Beryllis (Hyacinthaceae) in the Iberian Peninsula and the Balearic Islands. Belgian Journal of Botany 142: 140-162.

Martínez-Azorín, M., Crespo, M.B., Juan, A. \& Fay, M.F. (2011a) Molecular phylogenetics of subfamily Ornithogaloideae (Hyacinthaceae) based on nuclear and plastid DNA regions, including a new taxonomic arrangement. Annals of Botany 107: 1-37. https://doi.org/10.1093/aob/mcq207

Martínez-Azorín, M. Crespo, M.B., Pinter, M., Slade, J.M. \& Wetschnig, W. (2019a) Iosanthus (Hyacinthaceae subfam. Urgineoideae), a new genus from southern Africa to include Ornithogalum toxicarium and its removal from Ornithogaloideae. Plant Biosystems 153. [Published online 18 December 2018] https://doi.org/10.1080/11263504.2018.1527793

Martínez-Azorín, M. Crespo, M.B., Pinter, M. \& Wetschnig, W. (2017) Aulostemon (Asparagaceae, Scilloideae), a new genus from South Africa. Phytotaxa 321 (3): 287-293.

https://doi.org/10.11646/phytotaxa.321.3.6

Martínez-Azorín, M., Dold A.P. \& Crespo, M.B. (2016) Drimia trichophylla (Hyacinthaceae, Urgineoideae), a new species from the Eastern Cape Province, South Africa. Systematic Botany 41: 944-949. https://doi.org/10.1600/036364416X694044

Mucina, L. \& Rutherford M.C. (Eds.) (2006) The vegetation of South Africa, Lesotho and Swaziland. South African National Biodiversity Institute, Pretoria, 807 pp.

Müller-Doblies, U. \& Müller-Doblies, D. (1981) Über Verbreitung und Morphologie der Ornithogalum-Arten mit Zebrastreifung (Liliaceae des südlichen Afrika). Willdenowia 11: 45-67.

Nordenstam, B. (1970) Studies in South African Liliaceae. III. The genus Rhadamanthus. Botaniska Notiser 123: 155-182.

Obermeyer, A.A. (1978) Ornithogalum: a revision of the southern African species. Bothalia 12: 323-376. https://doi.org/10.4102/abc.v12i3.1793

Pinter, M., Crespo, M.B., Ilg, I., Luidold, A.K., Martínez-Azorín, M., Müller-Doblies, U., Müller-Doblies, D., Pfosser, M. \& Wetschnig, W. (2013) Mucinaea (Hyacinthaceae-Urgineoideae), a remarkable new genus from Namaqualand (Northern Cape Province, South Africa). Phyton 53: 289-304.

Pfosser, M. \& Speta, F. (1999) Phylogenetics of Hyacinthaceae based on plastid DNA sequences. Annals of the Missouri Botanical Garden 


\section{6: 852-875.}

https://doi.org/10.2307/2666172

Pfosser, M. \& Speta, F. (2001) Bufadienolides and DNA sequences: on lumping and smashing of subfamily Urgineoideae (Hyacinthaceae). Stapfia 75: 177-250.

Pfosser, M. \& Speta, F. (2004) From Scilla to Charybdis - is our voyage safer now? Plant Systematics and Evolution 246: 245 -263.

Pfosser, M., Knirsch, W., Pinter, M., Ali, S., Dutta, S. \& Wetschnig, W. (2012) Phylogenetic relationships of Malagasy Hyacinthaceae. Plant Ecology and Evolution 145: 65-72.

https://doi.org/10.5091/plecevo.2012.590

Rafinesque, C.S. (1837) Flora Telluriana 3. H. Probasco, Philadelphia, PA, 100 pp.

Speta, F. (1998a) Hyacinthaceae. In: Kubitzki, K. (Ed.) The families and genera of vascular plants 3. Springer, Berlin, pp. $261-285$. https://doi.org/10.1007/978-3-662-03533-7_35

Speta, F. (1998b) Systematische Analyse der Gattung Scilla L. s.l. (Hyacinthaceae). Phyton (Horn) 38: 1-141.

Speta, F. (2001) Die echte und die falsche Meerzwiebel: Charybdis Speta und Stellarioides Medicus (Hyacinthaceae), mit Neubeschreibungen und Neukombinationen im Anhang. Stapfia 75: 139-176.

Stedje, B. (1987) A revision of the genus Drimia (Hyacinthaceae) in East Africa. Nordic Journal of Botany 7: 655-666. https://doi.org/10.1111/j.1756-1051.1987.tb02034.x

Stedje, B. (1996) Hyacinthaceae. In: Polhill, R.M. (Ed.) Flora of Tropical East Africa. A.A. Bakelma, Rotterdam, pp. 1-32.

Stedje, B. \& Thulin, M. (1995) Synopsis of Hyacinthaceae in tropical East and North-East Africa. Nordic Journal of Botany 15: 591601 .

https://doi.org/10.1111/j.1756-1051.1995.tb02127.x

Thiers, B. (2019 [continuously updated]) Index Herbariorum: A global directory of public herbaria and associated staff. New York Botanical Garden's Virtual Herbarium. Available at http://sweetgum.nybg.org/ih/ (accessed August 2019)

Vlok, J.H.J. \& Euston-Brown, D.I.W. (2002) The patterns within, and the ecological processes that sustain, the Subtropical Thicket Vegetation in the planning domain for the Subtropical Thicket Ecosystem Planning (STEP) Project. Terrestrial Ecology Research Unit, University of Port Elizabeth, Port Elizabeth, 142 pp.

Willdenow, C.L. (1799) Caroli a Linné Species Plantarum. Editio Quarta, vol. 2 (1). Impensis G.C. Nauk, Berolini [Berlin], 823 pp.

Williamson, G. (2011) A new Drimia sp. from the Namib Desert in Namibia. Cactus and Succulent Journal 83: 286-289. https://doi.org/10.2985/0007-9367-83.6.286 